NBER WORKING PAPER SERIES

\title{
DO OLIGOPOLISTS POLLUTE LESS? EVIDENCE FROM A RESTRUCTURED ELECTRICITY MARKET
}

\author{
Erin T. Mansur \\ Working Paper 13511 \\ http://www.nber.org/papers/w13511
NATIONAL BUREAU OF ECONOMIC RESEARCH
1050 Massachusetts Avenue
Cambridge, MA 02138
October 2007

I would like to thank Severin Borenstein, Dallas Burtraw, Jim Bushnell, Ed Kahn, Nat Keohane, Steve Puller, Peter Schott, Chad Syverson, Chris Timmins, Frank Wolak, Catherine Wolfram, anonymous referees, and the editor for helpful suggestions. I also thank seminar participants at Berkeley, UCEI, Yale, and NBER. The views expressed herein are those of the author(s) and do not necessarily reflect the views of the National Bureau of Economic Research.

(C) 2007 by Erin T. Mansur. All rights reserved. Short sections of text, not to exceed two paragraphs, may be quoted without explicit permission provided that full credit, including $\odot$ notice, is given to the source. 
Do Oligopolists Pollute Less? Evidence from a Restructured Electricity Market

Erin T. Mansur

NBER Working Paper No. 13511

October 2007

JEL No. H23,L13,L33,L94,Q53

\begin{abstract}
$\underline{\text { ABSTRACT }}$
Electricity restructuring has created the opportunity for producers to exercise market power. Oligopolists increase price by distorting output decisions, causing cross-firm production inefficiencies. This study estimates the environmental implications of production inefficiencies attributed to market power in the Pennsylvania, New Jersey, and Maryland electricity market. Air pollution fell substantially during 1999, the year in which both electricity restructuring and new environmental regulation took effect. I find that strategic firms reduced their emissions by approximately $20 \%$ relative to other firms and their own historic emissions. Next, I compare observed behavior with estimates of production, and therefore emissions, in a competitive market. According to a model of competitive behavior, changing costs explain approximately two-thirds of the observed pollution reductions. The remaining third can be attributed to firms exercising market power.
\end{abstract}

Erin T. Mansur

Yale School of Management

135 Prospect Street

P.O. Box 208200

New Haven, CT 06520-8200

and NBER

erin.mansur@yale.edu 


\section{Introduction}

The world's largest restructured wholesale electricity market-the Pennsylvania, New Jersey, and Maryland Interconnection (PJM)-opened to competition in 1999. Regulators hoped to spur more efficient production and investment than had resulted under rate-of-return regulation. Electricity markets, however, are especially susceptible to the exercise of market power because they lack demand response and storage capability. ${ }^{1}$ In an oligopoly market with perfectly inelastic demand, market power leads to production inefficiencies because dominant firms reduce production and more expensive competitive fringe production is therefore required. ${ }^{2}$ This substitution of power plants has environmental implications. With perfectly inelastic demand, changes in air pollution emissions resulting from the exercise of market power will depend solely on the technologies that dominant firms use to withhold output in contrast with those that the competitive fringe uses to meet demand. ${ }^{3}$

Concurrent with the recent international movement of electricity restructuring, environmental regulators also unleashed market forces by establishing regional and national pollution permit markets. However, the effectiveness of incentive-based environmental regulation can be distorted by the structure of and competition in the polluting markets. Restructuring the PJM electricity market enabled firms to exhibit anti-competitive behavior in setting high price-cost margins (Mansur, forthcoming). In this paper, I explore whether this strategic behavior also altered producers' emissions, thereby changing the costs of complying with environmental regulation.

Air pollution from PJM electricity generators fell substantially from 1998 to 1999 when new environmental regulation and electricity restructuring took effect (see Figure 1$).{ }^{4}$ While overall elec-

\footnotetext{
${ }^{1}$ A number of studies find the exercise of market power in England (Wolak and Patrick, 1997; Wolfram, 1998; Wolfram, 1999), California (Borenstein, Bushnell, and Wolak, 2002; Puller, forthcoming; and Joskow and Kahn, 2002), New England (Bushnell and Saravia, 2002), and PJM (Market Monitoring Unit, 2001; Mansur, forthcoming). Consumers are sensitive to electricity prices (Bushnell and Mansur, 2005). However, the regulatory structure of electricity retail markets has kept the rate that consumers pay more or less constant. Furthermore, few consumers observe or are rewarded for responding to the real-time price of electricity. The derived demand for wholesale electricity is almost completely inelastic because utilities are mandated to provide customers with power at any cost (Borenstein, 2002).

${ }^{2}$ Each firm produces in a cost-minimizing manner, but dominant firms optimize by producing where marginal costs equal marginal revenue. This leads to cross-firm production inefficiencies.

${ }^{3}$ This paper focuses on short run effects when consumers' retail prices and producers' abatement technologies are fixed. The structure of the California electricity market suggests, for example, that market power may increase pollution while the PJM market is structured such that pollution will likely decrease. Section 2 elaborates on this point.

${ }^{4}$ Annual sulfur dioxide and carbon dioxide emissions from electric utilities fell by 13 and $12 \%$, respectively (Energy
} 
tricity production increased slightly to meet growing demand, the set of production technologies also changed. The relative increase in heavy polluters' input costs may explain reduced emissions. Beginning in 1999, the Ozone Transport Commission (OTC) mandated that Northeastern electricity producers possess tradable permits for summer nitrogen oxides $\left(\mathrm{NO}_{x}\right)$ emissions, permits that turned out to be quite expensive. ${ }^{5}$ Alternatively, restructuring may have led to market imperfections, including the exercise of market power, that caused production inefficiencies and reduced pollution. ${ }^{6}$

This study uses two methods to separate out these effects. First, I use a difference-in-differences model to test changes in firms' emissions. As a control group, I examine the behavior of New York firms, which were regulated by the OTC but are not located in PJM. I also compare the emissions of different firms in PJM. My findings suggest that the two firms with the most incentive to set high prices (PECO and PPL) reduced emissions substantially, approximately 20 percent, relative to other firms and their own historic emissions.

Next, in order to determine the implications on aggregate PJM emissions, I compare actual emissions with those of a simulated competitive market. The simulation uses a method developed by Wolfram (1999) and Borenstein, Bushnell, and Wolak (2002). My estimates of competitive production, which account for environmental regulation, explain approximately 64 percent of actual $\mathrm{NO}_{x}$ reductions. The remaining 36 percent can be attributed to firms exercising market power. Similar effects are found for emission reductions of sulfur dioxide $\left(\mathrm{SO}_{2}\right)$ and carbon dioxide $\left(\mathrm{CO}_{2}\right)$.

These two methods are complimentary in explaining the environmental consequences of strategic behavior. Namely, the exercise of market power by two firms in the PJM electricity market led to a reduction in emissions. Oligopoly behavior resulted in less pollution in PJM; this behavior accounts for approximately a third of the region's emissions reductions during the summer of 1999.

Information Administration (EIA), Electric Power Annual). These were the largest reductions in the 1990s for Delaware, Maryland, New Jersey, and Pennsylvania. Annual nitrogen oxides emissions were reduced by $17 \%$, second only to a $22 \%$ reduction in 1993 .

${ }^{5}$ However, states differed in how aggressive their firms were in abating pollution. For example, Massachusetts firms increased emissions from 1998 to 1999 (EIA Electric Power Annual). Sulfur dioxide emissions in the state increased from 98 thousand tons in 1998 to 113 thousand tons in 1999. Nitrogen oxides increased from 33 thousand tons to 41 thousand tons.

${ }^{6}$ In addition to market power, inefficiencies could also be caused by non-strategic firm behavior (e.g., confusing marginal and average costs) or by the market maker, PJM (e.g., flaws in the pricing algorithm). However, Mansur (forthcoming) provides empirical evidence supporting the hypothesis that these inefficiencies do stem from the strategic behavior of firms. Note that the environmental impacts of restructuring hold regardless of why the production efficiencies occurred. 
This paper studies whether imperfect competition in an output market can affect the environment. I assume a perfectly competitive permit market. While the exercise of market power in a permit market could also affect firms' emissions, this is not the intent of this study. To my knowledge, no studies have found evidence of market power in the OTC market.

The paper proceeds with Section 2 discussing the environmental implications of imperfect competition. Section 3 describes the environmental regulation and electricity restructuring in the MidAtlantic states. In Section 4, I present the difference-in-differences model and its results. Section 5 reviews the simulation method and provides evidence that restructuring resulted in production inefficiencies leading to emissions reductions in PJM. Section 6 discusses the economic consequences of these pollution reductions. Section 7 offers concluding remarks.

\section{Environmental Implications of Market Structure}

Economists have long understood the importance of considering market structure when determining environmental regulation. ${ }^{7}$ The problem of regulating a polluting monopoly is a common example of the theory of the second best. Placing a tax equal to the marginal external cost on a monopoly could result in larger welfare losses than ignoring the externality in a perfectly competitive market (Buchanan, 1969). ${ }^{8}$ Determining regulation in a second-best setting becomes more complicated when an imperfectly competitive market includes several producers. Levin (1985) demonstrates that Pigouvian taxes may increase pollution from an oligopolistic industry with asymmetric cost functions. The second-best tax may exceed the marginal external cost, since the market structure leads to production inefficiencies and distorts the total quantity produced (Simpson, 1995).

Like monopolists, oligopolists distort overall levels of production. However, an additional production substitution effect causes cross-firm production inefficiencies. Therefore, the pollution implications of a market's competitiveness depend on total production and the technologies employed, which result from several factors: demand elasticity, the distribution of technologies among firms, and the costs and emissions associated with various technology types. In addition, the exact

\footnotetext{
${ }^{7}$ See Fullerton and Metcalf (2002) for a recent summary of this literature.

${ }^{8}$ Buchanan notes that, when emissions depend only on output, an unregulated polluting monopolist may achieve the socially optimal level of output. Asch and Seneca (1976) extend this theory and discuss how many polluting industries are dominated by strategic firms. As noted by Endres (1978), Dnes (1981), and others, when abatement can be achieved by changing technologies, the monopolist will not achieve the first best. Nevertheless, understanding the impact of market structure on emissions decisions remains an important empirical question. This paper follows Buchanan's model in exploring the linkage between output decisions and pollution.
} 
oligopoly game will determine firm output.

As previously mentioned, many electricity markets consist of dominant firms with a competitive fringe facing perfectly inelastic demand. In this case, only technology substitution yields pollution effects. For example, emissions will fall if dominant firms reduce output from dirty plants and a competitive fringe meets demand using cleaner technology. In general, for this market structure, the environmental consequences of exercising market power depend only upon whether marginal production costs are increasing or decreasing in emission rates, assuming this relationship is monotonic. When expensive plants pollute more than cheap plants, market power increases emissions, and vice versa. $^{9}$

In the case of PJM, strategic firms will reduce output from coal, natural gas, or oil plants, depending upon the level of demand. Recall that a firm choosing to exercise market power will restrict output from its marginal "generating unit." 10 When demand ranges from low to medium levels, a strategic firm will have marginal coal units. Coal units tend to be substantially dirtier and cheaper, even including permit prices, than natural gas units. Therefore, restricting output with coal leads to more production by the fringe's gas units. On net, there will be fewer emissions in PJM than under perfect competition. However, exercising market power in electricity markets could also increase emissions when strategic firms and fringe producers use the same fuel type; variation in "heat rates" (a measure of efficiency) leads to a positive correlation between marginal costs and emissions rates. Hence, the effect in PJM will depend on the relative size of the across-technology substitution that reduces emissions and the within-technology substitution that increases emissions. I posit that the across-technology substitution is likely to dominate in many markets, including PJM. However, there are some markets where one would expect to see emissions increase as the result of strategic behavior. ${ }^{11}$

\footnotetext{
${ }^{9}$ The environmental impacts will be exacerbated if the dominant firms are more concentrated in low-cost technology. Mansur (2006) provides a formal model of the environmental implications of imperfect competition.

${ }^{10}$ Power plants consist of several, independently operating "generating units," each comprised of a boiler, a generator, and a smoke stack. For a given demand level, marginal units are the most expensive units a firm would operate under perfect competition.

${ }^{11}$ For example, California generators primarily use hydroelectric, nuclear, and natural gas to produce electricity, dominant firms' marginal units almost always burn gas. Therefore, firms opting to exercise market power will do so by restricting output from gas units. As high-cost gas units tend to be older, less efficient, and more polluting, I observe marginal production costs (including pollution permits) increasing in emissions (using data from Borenstein, Bushnell, and Wolak, 2002). One should expect the exercise of market power to increase pollution when dominant firms and fringe producers use the same fuel type as in California.
} 


\section{Environmental and Economic Regulation}

\subsection{Environmental Regulations}

In the summer of 1999, PJM wholesalers were subject to two incentive-based environmental regulations. One had just been introduced that summer, the OTC tradable permit regulation. In contrast, the Acid Rain Program had been in effect for a number of years but affected a smaller number of power plants at that time.

Several Northeastern states established the OTC program for summer $\mathrm{NO}_{x}$ emissions. For each ton emitted from May through September, power plant owners had to procure an allowance. If the permits were not used, they could have been 'banked' (in a limited manner) for future use. In 1999, Phase II of this program called for substantial reductions of greater than 50 percent from the 1990 emissions level baseline of 490,000 tons. In 1999, eight states participated, including New Jersey, Delaware, Pennsylvania, and New York. ${ }^{12}$

A firm has many options to comply with $\mathrm{NO}_{x}$ regulations. It can reduce output from dirty plants, install capital intensive equipment, or use low capital cost abatement techniques. A common capital intensive method is Selective Catalytic Reduction (SCR) technology that removes about 90 percent of emissions. Low capital cost options include low $\mathrm{NO}_{x}$ burners and other pre-combustion modifications, which abate 15 to 50 percent of emissions. (See Fowlie (2005) for a more detailed discussion of these abatement technologies.) For all emissions that are not abated, firms must pay a marginal cost for producing, either by purchasing permits or forgoing the opportunity to sell 'grandfathered' permits.

The permit market had a substantial effect on the marginal cost of production for many power plants in the Northeast. When the permit market started, in May of 1999, the permit price was $\$ 5244 /$ ton. This increased the marginal costs of some coal plants by 50 percent in comparison to the previous summer's costs. Many in the industry were concerned about firms 'hoarding' permits and the lack of announced equipment retrofits. However, the permit prices fell over the summer and reached $\$ 1093 /$ ton by mid-September. ${ }^{13}$

\footnotetext{
${ }^{12}$ The other states were in New England: Connecticut, Massachusetts, New Hampshire, and Rhode Island. Maryland began participating in the trading program in 2000. In addition, Maine, Vermont, northern counties in Virginia, and the District of Columbia were part of the commission but did not partake in the tradable permit regime. Sources may have been constrained by other federal and state environmental regulations.

${ }^{13}$ Just after the regulatory period the bankable permits traded at $\$ 825 /$ ton. Since the first summer, the price remained around $\$ 1000 /$ ton (see http://www.epa.gov/airmarkets/otc/).
} 
Title IV of the 1990 Clean Air Act Amendments, the Acid Rain Program, established a national tradable permits system for annual $\mathrm{SO}_{2}$ emissions. As a result, power plant emissions have been reduced to approximately 50 percent of 1980 levels. A firm can opt to purchase permits, reduce production, switch to low sulfur coal, or install a scrubber. ${ }^{14}$ Excess permits can be traded to other firms or held for future use by banking them. Phase I began in 1995, regulating the 398 dirtiest generating units in the US. In 2000, Phase II brought over 2,300 fossil fuel units into compliance. The increase in the scope of regulated firms was accompanied by an increase in permits, while overall, Phase II requires more abatement.

Twenty-three units at ten plants in PJM were regulated by Phase I. Regardless of how these units complied with the regulation, the price of the permit is the opportunity cost of polluting. During the summer of 1999 , the price of these allowances was about $\$ 200$ per ton. For the median coal unit regulated by Title IV, this corresponds to about three dollars per megawatt-hour (MWh). The average Phase II unit is cleaner with an expected marginal cost of approximately one dollar per MWh at these prices. ${ }^{15}$

\subsection{The PJM Electricity Market}

In 1998 and 1999, the whole of New Jersey, Delaware and the District of Columbia, the majority of Pennsylvania and Maryland, and part of Virginia comprised the PJM Interconnection market's regulatory bounds. ${ }^{16}$ The PJM market required firms to offer bids to supply electricity from each generating unit into a day-ahead uniform-price auction. In 1998, PJM mandated that bids equal marginal costs as determined from years of regulation rate hearings. Mansur (forthcoming)

\footnotetext{
${ }^{14}$ Compliance options for $\mathrm{SO}_{2}$ and $\mathrm{NO}_{x}$ regulations have few direct economies of scope: for example, switching to low sulfur coal does not lower $\mathrm{NO}_{x}$ emissions; scrubbers and SCR are additive technologies that only remove their respective pollutants; and low $\mathrm{NO}_{x}$ burners make plants less efficient (thereby increasing the $\mathrm{SO}_{2}$ emissions per MWh). However, firms may be able to reduce overall abatement costs by complying with multiple pollutant regulations simultaneously. (For example, a firm could retire a coal plant and build a natural gas plant.) There are scope economies in other environmental regulations: for example, they exist when $\mathrm{SO}_{2}, \mathrm{NO}_{x}$ and mercury are regulated jointly (Palmer et al., forthcoming) and there are also scope economies between $\mathrm{NO}_{x}$ and carbon dioxide (Burtraw et al., 2003). As with many capital intensive investments, scrubbers and SCR do exhibit some economies of scale and are likely to be placed on larger and newer plants.

${ }^{15}$ In Phase I, the median heat rate was $10,179 \mathrm{BTU} / \mathrm{kWh}$ and the median emissions factor was $2.93 \mathrm{lbs}$. of $\mathrm{SO}_{2} / \mathrm{mmBTU}$. In Phase II, I assume a heat rate of $12,000 \mathrm{BTU} / \mathrm{kWh}$ and an emissions factor of $1.2 \mathrm{lbs}$. of $\mathrm{SO}_{2} / \mathrm{mmBTU}$.

${ }^{16} \mathrm{PJM}$ facilitates trade among regulated utilities and independent producers involved in the generation, transmission, and distribution of electricity. In doing so, the wholesale market attempts to lower utilities' costs of providing power to customers. The PJM wholesale electricity market established a new pricing network in 1998 to facilitate inter-utility trading.
} 
measures competitive prices that approximately equal actual prices during the summer of 1998. In April 1999, the market operators restructured the market again by allowing for competition in the wholesale electricity spot market. The Federal Energy Regulatory Commission (FERC) granted most firms the right to switch from "cost-based" bidding to unregulated, "market-based" bidding. As discussed below, prices were much greater during the summer of 1999 .

Figure 2 plots the market supply curve that consists of a mix of nuclear, hydroelectric, coal, natural gas, and oil energy sources. The four largest firms-Public Service Electric, PECO, GPU, and PPL-account for two thirds of the market's 57,000 megawatts (MW) of capacity and use all these energy sources (see Table 1). Nuclear and coal plants provide baseload generation capable of covering most of the demand. Nuclear power comprises 45 percent of generation but only 24 percent of capacity. In contrast, natural gas and oil burning units provide over 35 percent of the market's capacity, yet they operate only during peak demand times. These differences in production result from heterogeneous cost structures. Baseload units have low marginal costs but are expensive to start and slow to increase production. In contrast, the relatively flexible peaking units are more expensive to operate.

Emissions rates vary substantially both within and across fuel types. Figure 3 shows the $\mathrm{SO}_{2}$ emissions rates, which correspond to the units in Figure 2, using data from the EPA's Continuous Emissions Monitoring System (CEMS). ${ }^{17}$ Coal units tend to emit more $\mathrm{SO}_{2}$ than oil units while natural gas only has trace amounts of $\mathrm{SO}_{2}$. Table 2 provides the summary statistics of emissions rates by fuel type. Coal units' average $\mathrm{SO}_{2}$ emissions rate of $20.3 \mathrm{lbs}$ per $\mathrm{MWh}$ is approximately three times that of oil units and vastly higher than gas units. For $\mathrm{NO}_{x}$ emissions rates, coal units average $5.8 \mathrm{lbs}$ per MWh. This average is greater than the average for oil or gas but not as dramatically different as $\mathrm{SO}_{2}$ rates. $\mathrm{CO}_{2}$ emissions rates vary the least across fuels or even within fuels. $^{18}$

\footnotetext{
${ }^{17}$ In order to comply with the 1990 Clean Air Act, fossil-fuel generating electric producers are required to report hourly emissions and electricity production by unit. Regulation affects units of 25 MW capacity plus new units under 25 megawatts that use fuel with a sulfur content greater than $0.05 \%$ by weight. CEMS records hourly gross production of electricity, heat input, and emissions of $\mathrm{SO}_{2}, \mathrm{NO}_{x}$, and carbon dioxide for most fossil units in the country. During the summers of 1998 and 1999, CEMS monitored 234 units that accounted for over 97 percent of PJM's fossil fuel capacity. Gross generation includes the electricity generated for sales (net generation) as well as the electricity produced to operate that power plant. Typically net generation is approximately 90 to 95 percent of gross generation. I define emissions rates as the ratio of the aggregate summer pollution over the aggregate summer gross generation. CEMS data are highly accurate and comprehensive for most types of fossil units (Joskow and Kahn, 2002).

${ }^{18}$ To compare variation in rates within a fuel type, I calculate the coefficient of variation (standard deviation over
} 
In PJM, the large firms are vertically integrated in generation, transmission, and distribution. They sell electricity into the wholesale market, but also must procure electricity to sell to retail customers, called "native load." The rate that the firms can sell to their customers was fixed by regulators. Panel B of Table 1 reports each firm's market share of capacity, generation, and peak demand of its customers' native load. On average, the generation of two Pennsylvania firms, PECO and PPL, exceeded their native load. These firms had the most incentive to set high prices and did reduce output relative to competitive levels (Mansur, forthcoming).

Table 3 provides descriptive statistics about demand, electricity prices, and input prices during the summers of 1998 and 1999. While demand rose three percent, the market price was 46 percent higher in 1999. This was, in part, due to higher input prices for oil, natural gas, and $\mathrm{SO}_{2}$ permits. The introduction of the OTC $\mathrm{NO}_{x}$ trading program had the largest impact on costs.

Firms did not respond to these demand and cost shocks symmetrically. For the summers of 1998 and 1999, Table 4 reports on the aggregate generation of the strategic firms, PECO and PPL, compared with that of the fringe by fuel type. In 1999, PECO and PPL production dropped for coal and oil generating units. The fringe also reduced output from its coal power plants, while its oil production increased. Either technology or incentive asymmetries could cause firms to respond differently in 1999. If the strategic firms owned units with relatively high $\mathrm{NO}_{x}$ emissions rates, one might expect the OTC program to have affected these firms more so than others. Alternatively, the oligopolists may have reduced output in exercising market power.

In order to separate out these explanations, the following sections account for demand and cost shocks in measuring the environmental effects of exercising market power in the PJM wholesale electricity market. The method in Section 4 asks whether the strategic firms responded differently to OTC regulation than other firms in their emissions choices. Section 5 then measures the equilibrium implications of imperfect competition.

mean) for each fuel and pollutant. For coal, oil, and gas, the coefficients of variation are 0.45 , 1.36, and undefined for $\mathrm{SO}_{2} ; 0.50,0.77$, and 0.89 for $\mathrm{NO}_{x}$; and $0.14,0.26$, and 0.15 for $\mathrm{CO}_{2}$, respectively. 


\section{Difference-in-Differences Model}

\subsection{Method}

Using a difference-in-differences model, this section examines the actual emissions decisions of various groups of firms over the summers (April to September) of 1998 and 1999. Environmental regulations and generation characteristics vary substantially among power plants within a firm. Furthermore, demand varies significantly hour by hour and electricity is not storable. Thus, I analyze plant-hour level decisions.

The treatment group includes power plants controlled by PECO and PPL, the oligopolists $\left(\right.$ Olig $\left._{i}\right)$, after PJM was restructured. Recall that PJM was restructured on April 1, 1999, while the OTC did not start until May 1, 1999. Given the timing and spatial variation of the OTC regulation and PJM restructuring, there are several potential comparison groups.

The primary control group for the OTC regulation consists of New York plants $\left(N Y_{i}\right)$. As with PECO and PPL, New York plants were regulated by the OTC starting May 1, 1999. Restructuring of the New York electricity market did not occur until the following winter.

A possible control group for PJM restructuring is all of the competitive fringe plants in the southern part of PJM $\left(S o P J M_{i}\right)$, consisting of Maryland, Virginia, and Washington, DC. These firms were not part of the OTC region in 1999, allowing me to pool the April through September months for these plants $\left(\right.$ AprSept $\left.99_{t}\right) .{ }^{19}$

An additional control group consists of northern PJM plants $\left(N o P J M_{i}\right)$ regulated by OTC (in New Jersey, Delaware, and Pennsylvania). The oligopolists are both located in northern PJM. In April of 1999, PJM had restructured but the OTC was not in effect. Therefore, for all northern PJM plants (as well as specifically for the oligopoly plants), I can examine the emissions behavior both before $\left(\operatorname{Apr} 99_{t}\right)$ and after $($ MaySept99t) the OTC regulation took effect.

For actual $\mathrm{NO}_{x}$ emissions $\left(E_{i t}\right)$ at plant $i$ and hour $t$, I estimate a plant-specific fixed effects

\footnotetext{
${ }^{19}$ These firms did not exercise market power either before or after restructuring (Mansur, forthcoming). Starting in 2000, the firms in Maryland, Virginia, and Washington, DC, were regulated by the OTC.
} 
$\left(\alpha_{i}\right)$ model of the form:

$$
\begin{aligned}
\ln \left(E_{i t}\right)= & \alpha_{i}+\beta_{1} N Y_{i} \cdot \text { MaySept } 99_{t}+\beta_{2} \text { SoPJ }_{i} \cdot \text { AprSept } 99_{t} \\
& +\beta_{3}{\text { NoPJ } M_{i} \cdot \text { Apr } 99_{t}+\beta_{4} \text { NoPJM }}_{i} \cdot \text { MaySept } 99_{t} \\
& +\beta_{5} \text { Olig }_{i} \cdot \text { NoPJM }_{i} \cdot{\text { Apr } 99_{t}+\beta_{6} \text { Olig }_{i} \cdot N o P J M_{i} \cdot \text { MaySept }_{4}}_{t} \\
& +\gamma_{1} \ln \left(P_{t}^{\text {Gas }}\right)+\gamma_{2} \ln \left(P_{t}^{\text {Oil }}\right)+\gamma_{3} \ln \left(P_{t}^{\text {SO } 2}\right)+\delta \ln \left(\text { Load }_{i t}\right)+\varepsilon_{i t},
\end{aligned}
$$

where $P_{t}^{\text {Gas }}, P_{t}^{\mathrm{Oil}}$, and $P_{t}^{S O 2}$ are the national or regional spot market prices of natural gas, oil, and $\mathrm{SO}_{2}$ permits, respectively. Loadit is the hourly system load for the market in which plant $i$ is located. The idiosyncratic shocks, $\varepsilon_{i t}$, are clustered at the plant level to address serial correlation and heteroskedasticity. ${ }^{20}$

\subsection{Data}

The CEMS data provide hourly output and emissions information on most fossil fuel generating units in the US (see footnote 17). These data are aggregated to the plant-hour level. Some plants do not operate for long periods of time either because they are under maintenance or are "mothballed." Therefore, I only include plants that have operated in the past week. The CEMS data are merged with data on plant characteristics including plant location, ownership, primary fuel source, and capacity (from EPA's 1998 Egrid data). Hourly load for PJM and New York are from the PJM web site (www.pjm.com) and FERC Form 714, respectively.

I measure fuel prices using spot prices of oil and natural gas while assuming constant coal costs. $^{21}$ EIA provides data on the daily spot price of New York Harbor No. 2 heating oil. Natural Gas Intelligence provided daily natural gas spot prices for Transco Zone 6 non-New York. To calculate $\mathrm{SO}_{2}$ regulation costs, I use the mean of two monthly price indices of $\mathrm{SO}_{2}$ permit prices that brokerage firms Cantor Fitzgerald and Fieldston report to the EPA.

\footnotetext{
${ }^{20}$ Bertrand, Duflo, and Mullainathan (2004) argue that many papers using DID estimation are problematic due to the correlation of the group effects and the autocorrelation in the residuals $\varepsilon_{i t}$. They suggest several ways to address autocorrelation in this setting, including using the cluster command in Stata. As discussed below, I test the robustness of this method using both a Newey-West correction for serial correlation and a generalized least squares $\mathrm{AR}(1)$ model. I also test clustering at the firm level.

${ }^{21}$ While spot markets for coal exist, the heterogeneous product trades on more dimensions than simply price and quantity. Factors such as moisture, ash content, sulfur content, and location determine the type of coal being traded. Rather than modeling each plants coal costs, I impose constant prices for delivery of coal.
} 


\subsection{Results}

Tables 5, 6, and 7 summarize the results using the difference-in-differences method. For each table, the $\beta_{1}, \beta_{2}, \beta_{3}$, and $\beta_{4}$ parameters in (1) estimate the change in emissions for each control group. For example, "NoPJM$M_{i} \cdot$ MaySept99" equals one for a plant located in northern PJM (in either NJ, DE, or PA) during the time that both restructuring and the OTC regulation were in effect. Given the log specification of the dependent variable, each $\beta$ parameter can be interpreted as the average percent change in emissions relative to these plants' 1998 summer emissions.

The oligopolists' coefficients, $\beta_{5}$ and $\beta_{6}$, estimate the incremental changes in emissions for the oligopolists relative to $\beta_{3}$ and $\beta_{4}$, respectively. For example, "Oligi $\cdot$ NoPJM$M_{i} \cdot$ MaySept99" indicates that a plant is owned by an oligopolist (all oligopolists' plants are in NoPJM), and that restructuring and OTC regulation are in effect. These coefficients indicate how much more the oligopolists reduced their emissions during this period than fringe firms, relative to their previous emissions.

Table 5 reports the main findings of the impact of restructuring and the OTC $\mathrm{NO}_{x}$ regulation on the $\log$ of $\mathrm{NO}_{x}$ emissions (in pounds). The first column shows the results of a regression with only plant fixed effects and the plant group variables (i.e., those variables in (1) with $\beta$ coefficients). Firms in New York did not significantly change their plants' emissions from the summer of 1998 to the summer of 1999. Also, plants in the PJM region but outside of the OTC regulation (SoPJM) did not change their emissions significantly. However, the fringe firms in New Jersey, Delaware, and Pennsylvania (NoPJM) did reduce emissions both before and after the OTC regulation.

The treatment group behaved differently than the various control groups. Namely, after the OTC regulation, the oligopolists (PECO and PPL) reduced $\mathrm{NO}_{x}$ emissions substantially more than did firms in other groups. The $\beta_{6}$ parameter from (1) equals -0.214 (and is significant at the five percent level). This coefficient implies that these firms reduced emissions by approximately 20 percent relative to their historic emissions and the response of other northern PJM plants.

Column (1) does not account for the changes in market conditions mentioned above, such as the three percent increase in PJM demand. These market conditions are accounted for in Columns (2), (3), and (4). Column (2), which includes $\ln ($ Load), reports that New York firms did, in fact, reduce emissions given the new OTC regulation. Emissions fell by approximately 15 percent over the two summers. Southern PJM fringe firms reduced emissions by 20 percent but these reductions 
are only weakly significant (i.e., significant at the 10 percent level). ${ }^{22}$ Controlling for demand, the emissions of northern PJM fringe firms in April 1999 were not significantly different from those of the previous summer. However, after the OTC took effect, they reduced emissions by 34 percent. PECO and PPL may have reduced emissions even in the first month following restructuring, but the large standard errors preclude such a finding. ${ }^{23}$ Once the OTC regulation was binding, the oligopolists reduced emissions by approximately 20 percent more than any other group. ${ }^{24}$

The results of Column (2) are robust to several other model specifications. Column (3) includes control variables for changes in input prices. Column (4) includes these input price variables and tests the functional form assumption on the log of load by modeling it as a piece-wise linear spline (split by quintile). Column (5) constrains the behavior of northern PJM firms $\left(\beta_{3}=\beta_{4}\right)$ and oligopolist firms $\left(\beta_{5}=\beta_{6}\right)$ to be the same before and after the OTC regulation. Again, strategic firms' emissions reductions are significantly greater in magnitude than other firms. As the model shown in Column (4) is the most flexible, I consider it to be the main model. In the appendix, I find these results to be robust to several alternative specifications of the variables and error structure.

Table 6 examines whether these results differ by fuel type and plant size. The model from Table 5 , Column (4), is applied to just the coal-fired power plants and then to only the big coal plants. ${ }^{25}$ Gas and oil plants are also examined in a similar manner. ${ }^{26}$ After the OTC regulation began, all OTC regulated firms emitted less from coal plants. In addition, the oligopolists reduced emissions from oil plants significantly more so than did the control groups. ${ }^{27}$ In contrast, the emissions from northern PJM fringe big oil plants (and from New York big gas plants) increased substantially from 1998 to 1999.

\footnotetext{
${ }^{22}$ Baltimore Gas \& Electric installed $\mathrm{NO}_{x}$ abatement technology at a few plants in 1999. It installed oven fired air controls at two boilers at its C.P. Crane plant. It also installed low NOx burners at a boiler in its Gould Street plant and in a boiler at its H.A. Wagner plant. This is based on EIA Form 767. These investments were probably in preparation of being regulated by the OTC in the coming years.

${ }^{23}$ April 1999 was the first month after PJM was restructured. If firms required time to learn the rules of the market and their competitors' behavior, then this month may exhibit less market power. Borenstein, Bushnell, and Wolak (2002) exclude the first month after California was restructured due to oddities in the new electricity market.

${ }^{24}$ In addition to the significance of $\beta_{6}$, a Wald test implies that the oligopolists were also significantly different from the New York firms after the OTC $(\mathrm{F}=16.99$, Prob $=0.0001)$.

25 "Big" is defined as above the median capacity for a given fuel type. One could also examine "dirty" and "clean" plants by fuel type. However, a regression analysis that used emissions rates to split the sample may potentially face endogeneity issues.

${ }^{26} \mathrm{PECO}$ and PPL do not have any power plants in the CEMS data that are primarily gas fired. In contrast, Table 4 summarizes the output of all generating units, which includes some gas units.

${ }^{27} \mathrm{~A}$ Wald test implies that oligopolists did emit more from oil units relative to their 1998 emissions $(\mathrm{F}=4.23$, Prob $=0.0450)$ : i.e., $\beta_{4}+\beta_{6}=0$. This was also the case for big oil units $(\mathrm{F}=5.82$, Prob $=0.0302)$.
} 
The difference in emissions at peaking plants (i.e., oil and gas plants) between the oligopolists and fringe firms is consistent with strategic behavior. Recall that demand is perfectly inelastic so if some plants-controlled by strategic firms-produce less, others must produce more. While this will be true of coal plants as well, they have lower costs (making them inframarginal in many hours) and reductions may be less transparent, on average.

Table 7 reports changes in other pollutants $\left(\mathrm{SO}_{2}\right.$ and $\left.\mathrm{CO}_{2}\right)$ and in electricity output. For comparison, the first column repeats the main results of Table 5, Column (4). Column (2) of Table 7 shows that the oligopolists reduced $\mathrm{SO}_{2}$ emissions (in pounds) by over 20 percent after the OTC regulation began, relative to the control groups. However, the effect is only weakly significant. No other groups changed behavior significantly from their 1998 emissions.

In Columns (3) and (4) of Table 7, $\mathrm{CO}_{2}$ emissions (in tons) and electricity output (in MWh) did not change for New York firms after the start of the OTC regulation. In contrast, all northern PJM firms reduced both $\mathrm{CO}_{2}$ emissions and output after the introduction of the OTC regulation. While the coefficients on oligopolists' $\mathrm{CO}_{2}$ emissions and output (relative to other northern PJM firms) are negative after the OTC, they are imprecisely estimated (they are weakly significant and insignificant at the 10 percent level, respectively).

The results of Tables 5-7 correct for serial correlation and heteroskedasticity by clustering the errors at the plant level. An alternative and equally plausible method is to calculate Newey-West standard errors. The coefficients remain the same as in Column (4) of Table 7, but the standard error on $\beta_{6}$, assuming a six hour lag structure, is only 0.019 . With this specification, the oligopoly coefficient is highly significant. (This is also the case for the other columns in Table 7.) These output reductions by the oligopolists support the findings of Mansur (forthcoming). A comparison of these results with those of Column (1) suggests that changes in a firm's average plant output (at least partially) explain the reductions in $\mathrm{NO}_{x}$.

From this analysis, I conclude that-when compared to the New York plants control group-the strategic firms in PJM substantially reduced $\mathrm{NO}_{x}, \mathrm{SO}_{2}$, and $\mathrm{CO}_{2}$ emissions and output during May to September, 1999, from the previous summer's levels. These results suggest that the large reductions in emissions observed in PJM during 1999 (see Figure 1) resulted in part due to strategic behavior of firms in the restructured PJM market. In order to quantify the implications of market power on the aggregate PJM emissions, Section 5 simulates what the emissions would have been 
in a competitive market.

\section{Simulation of a Competitive Market's Emissions}

This section measures the environmental implications of strategic behavior in the PJM wholesale electricity market using a simulation model of competitive behavior. For both the summer of 1998 and the summer of 1999, I compare observed emissions of pollutant $j\left(E_{j}\right)$ with emissions from a model of perfectly competitive behavior $\left(E_{j}^{*}\right)$. For each summer, I calculate the change in $\mathrm{SO}_{2}$, $\mathrm{NO}_{x}$, and $\mathrm{CO}_{2}$ emissions: $E_{j}-E_{j}^{*}$.

The environmental implications of firms exercising market power will depend on the reduced emissions from strategic firms and the increased emissions from the fringe firms in PJM. To measure this effect, I use CEMS data on observed emissions $\left(E_{i j t}\right)$ for unit $i$, pollutant $j$, and hour $t$. For each unit $i$, pollutant $j$, and hour $t$, the counterfactual competitive emissions are calculated as the product of the emissions rate $\left(r_{i j}\right)$ of unit $i$ and its output in a competitive market $\left(q_{i t}^{*}\right)$.

Furthermore, as strategic behavior increases prices and reduces generation in PJM, net imports (namely, imports net of exports) will increase relative to the competitive counterfactual. Net imports $\left(q_{t}^{i m p}\right)$ are a function of price, either actual $\left(p_{t}\right)$ or the competitive simulation $\left(p_{t}^{*}\right)$. In a given hour $t$, the change in emissions from net imports equals the emissions rate of import supply $\left(r_{j t}^{i m p}\right)$ times the change in imports $\left(q_{t}^{i m p}\left(p_{t}\right)-q_{t}^{i m p}\left(p_{t}^{*}\right)\right)$.

Summing over the $T$ hours and $N$ units in a given summer, the total environmental effect of firms exercising market power in the PJM electricity market can be written as the change in emissions by PJM firms plus the change in emissions associated with imports:

$$
E_{j}-E_{j}^{*}=\sum_{t=1}^{T}\left\{\sum_{i=1}^{N}\left[E_{i j t}-r_{i j} q_{i t}^{*}\right]+r_{j t}^{i m p}\left[q_{t}^{i m p}\left(p_{t}\right)-q_{t}^{i m p}\left(p_{t}^{*}\right)\right]\right\} .
$$

For the competitive counterfactual, I calculate each unit's emissions rates, $r_{i j}$. One possible explanation for the reduction in emissions from 1998 to 1999 is that some of the firms may have invested in improved abatement technology. Firms may have been preparing for the tightening of the national $\mathrm{SO}_{2}$ permit market in 2000. In actuality, no power plant in PJM installed a scrubber in 1999. Even with the new $\mathrm{NO}_{x}$ market, only a few plants installed $\mathrm{NO}_{x}$ abatement technology from 1998 to $1999 .{ }^{28}$ In general, PJM firms' emissions rates did not change significantly over this

\footnotetext{
${ }^{28}$ From 1998 to 1999, Delmarva installed low NOx burners at two boilers at its Indian River plant. PECO installed
} 
time period. ${ }^{29}$ Nevertheless, some units' rates did change so this analysis uses data on emissions rates averaged over a summer. ${ }^{30}$

\subsection{Competitive Production Model}

I use predictions of competitive behavior, $q_{i t}^{*}$, that are described in Mansur (forthcoming). This method has been used to calculate competitive equilibrium in many markets. Two notable papers are by Wolfram (1999) on the England and Wales market and by Borenstein, Bushnell, and Wolak (2002) on the California market.

For each hour $t$, the model solves for the equilibrium price of a competitive market. Electricity is supplied by some technologies that are capable of responding to prices like fossil units $\left(q_{t}^{f}\right)$. Other technologies, like hydroelectric $\left(q_{t}^{h}\right)$ and nuclear generation $\left(q_{t}^{n}\right)$, are assumed not to respond to prices. The residual demand that firms in PJM face is equal to the market demand $\left(\bar{q}_{t}\right)$, which is perfectly elastic, minus the production from importers (net of exports) into PJM $\left(q_{t}^{i m p}\right)$. The equilibrium price, $p_{t}^{*}$, is such that the amount supplied equals the amount demanded:

$$
q_{t}^{f}\left(p_{t}^{*}\right)+q_{t}^{h}+q_{t}^{n}=\bar{q}_{t}-q_{t}^{i m p}\left(p_{t}^{*}\right)
$$

The supply curve of net imports is written as a function of actual price $\left(p_{t}\right)$ :

$$
q_{t}^{i m p}=\beta_{1} \ln \left(p_{t}\right) \cdot P e a k_{t}+\beta_{2} \ln \left(p_{t}\right) \cdot\left(1-P e a k_{t}\right)+\mathbf{X}_{t}^{\prime} \gamma+\varepsilon_{t}
$$

where Peak $k_{t}$ indicates hours between $11 \mathrm{AM}$ and $8 \mathrm{PM}$ on weekdays and $X_{t}$ is a vector of temperature and indicator variables.

biased firing alternate burners at two boilers at its Eddystone plant and low NOx burners at two other boilers at the same plant. The investments of Baltimore Gas \& Electric are mentioned in footnote 22. This is based on EIA Form 767.

${ }^{29}$ The EPA compiles data on electricity generators in the Egrid data set. Egrid includes data on the annual average emissions rate of $\mathrm{SO}_{2}, \mathrm{NO}_{x}$, and $\mathrm{CO}_{2}$ for each power plant in the US. For the plants in PJM, I calculate the change in plant emissions rates from 1998 to 1999 and regress annual emissions rates during 1998 and 1999 on plant fixed effects and an indicator of 1999. Changes in emissions rates from technological adoption are decided jointly at the level of the firm. Therefore, the standard errors were corrected for common shocks within a utility using Stata's cluster command. Rates were lower in 1999 but none of the changes were significant at the five percent level. $\mathrm{SO}_{2}$

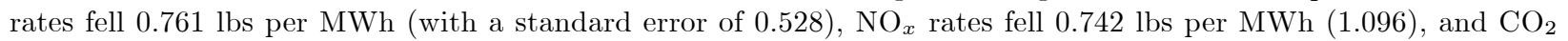
fell 0.057 tons per MWh (0.066).

${ }^{30}$ The emissions rates are equal to the total summer emissions divided by the total summer gross generation. These CEMS rates are merged, by unit, with the competitive simulation model. The simulation uses data on heat rate, fuel type, capacity, and another set of emissions rates from the PROSYM model (Kahn, 2000). The identification of the units in CEMS and PROSYM did not match for many units. Given the matching problems, I use the average of the emissions rates when a unit is in both data sets. For units with only one set of emissions, only that rate is used. 
The fossil units are modeled as producing at capacity $\left(K_{i}\right)$ whenever price equals, or exceeds, its marginal cost $\left(c_{i t}\right)$. Marginal costs are a function of daily input prices for fuels $\left(W_{i t}^{f u e l}\right), \mathrm{SO}_{2}$ permits $\left(W_{t}^{S O_{2}}\right)$, and $\mathrm{NO}_{x}$ permits $\left(W_{t}^{N O_{x}}\right)$, as well as unit-specific characteristics of efficiency (i.e., heat rate $\left.H R_{i}\right)$, emissions rates $\left(r_{i}^{S_{2}}\right.$ and $\left.r_{i}^{N O_{x}}\right)$, and variable operating and maintenance costs $\left(V O M_{i}\right)$ :

$$
c_{i t}=V O M_{i}+H R_{i} \cdot\left(W_{i t}^{f u e l}+W_{i t}^{S O_{2}} r_{i}^{S O_{2}}+W_{i t}^{N O_{x}} r_{i}^{N O_{x}}\right) .
$$

Whenever a firm attempts to generate using unit $i$, there is some probability, $f_{i}$, that the unit will not be able to operate. ${ }^{31}$ The model accounts for these outages by using Monte Carlo simulations. For each hour in the sample, outages are simulated by drawing $\xi_{i t}$ from a $[0,1]$ uniform distribution. If $\xi_{i t}$ is less than $f_{i}$, the unit cannot operate. Therefore, the fossil unit production in a competitive model is:

$$
q_{i t}^{*}\left(P_{t}^{*}\right)=\left\{\begin{array}{l}
K_{i} \text { if } p_{t}^{*} \geq c_{i t} \text { and } \xi_{i t}>f_{i} \\
0 \quad \text { otherwise. }
\end{array}\right.
$$

A competitive price and output for each unit are calculated for each hour and Monte Carlo simulation. A unit's hourly production, $q_{i t}^{*}$, equals the mean of 100 simulation draws.

\subsection{Emissions from Imports}

When PJM firms exercise market power, generating units throughout the Eastern grid must produce more to satisfy PJM demand. This section estimates the emissions associated with the import supply curve. I calculate the correlation during the summer of 1999 between PJM net imports and production throughout the East. Production data are gathered from CEMS for every generating unit in the Eastern grid but not in PJM. ${ }^{32}$ The firms owning these units make production decisions based on prices in PJM and their local areas outside of PJM. I use temperature variables to proxy for local prices in other regions. The correlation between a unit's production and total PJM imports is directly examined rather than measuring the impact of PJM price on a unit's production and then imposing that prices affect the aggregate production of firms exactly the same as they affect

\footnotetext{
${ }^{31}$ Outages are relatively common at power plants. In my sample of 392 generating units in PJM, this "forced outage factor" averaged 0.065 and ranged from 0.027 to 0.089 .

${ }^{32}$ While transmission constraints are likely to make some units much more likely to sell power to PJM, it is possible that any unit could sell the electricity. As the estimates are for each unit separately, the data will allow me to posit which ones are actually the source of imports.
} 
measured imports. For each unit $i$ not in PJM, the following equation is estimated:

$$
q_{i t}=\alpha_{i}+\delta_{i} q_{t}^{i m p}+\phi_{1, i} T_{i t}+\phi_{2, i} T_{i t}^{2}+\varepsilon_{t}
$$

where $q_{i t}$ is hourly production, $q_{t}^{i m p}$ is PJM imports (net of exports), and $T_{i t}$ is the unit $i$ 's state daily mean temperature. ${ }^{33}$

The estimated $\widehat{\delta}_{i}$ coefficients are calibrated to sum to one, imposing that the total change in imports equals the total change in production outside of PJM:

$$
\widetilde{\delta}_{i}=\widehat{\delta}_{i} / \sum_{j=1}^{M} \widehat{\delta}_{j},
$$

where $M$ is the sample of units in the Eastern grid not in PJM. The implied emissions from imports equal $q_{t}^{i m p} \cdot\left(\sum_{i=1}^{M} \widetilde{\delta}_{i} r_{i j}\right)$, where $r_{i j}$ is the emissions rate for unit $i$ and pollutant $j$. Estimates of imports in the competitive scenario are measured in Mansur (forthcoming). ${ }^{34}$ Over the summer of 1999, actual imports were greater than those predicted by the competitive model by a total of 463,587 MWh.

\subsection{Results}

Table 8 reports total summer emissions in PJM using actual data and simulations from the competitive model. From the summer of 1998 to the summer of 1999, actual emissions fell substantially. $\mathrm{SO}_{2}$ emissions fell from 631,898 tons in 1998 to 539,602 tons in 1999 . This is a 15 percent reduction. $\mathrm{NO}_{x}$ emissions had an even larger percent drop of 21 percent between these summers. $\mathrm{CO}_{2}$ emissions fell 6,976,420 tons, or nine percent.

The competitive model's predictions of changes in emissions are smaller than those observed. I find that the implied reduction in PJM emissions explained by cost and demand shocks was only 41,883 tons of $\mathrm{SO}_{2}$, which is a reduction of eight percent. $\mathrm{NO}_{x}$ emissions decreased 14 percent, or by 26,024 tons. $\mathrm{CO}_{2}$ emissions were reduced by 5,132,820 tons (six percent). Note that for 1998 the model predicts fewer $\mathrm{SO}_{2}$ emissions but greater $\mathrm{NO}_{x}$ and $\mathrm{CO}_{2}$ emissions than actually occurred.

\footnotetext{
${ }^{33}$ Firms' production decisions will certainly depend on factors beyond temperature. This is particularly true for those firms in other restructured electricity markets, such as New England. However, the intent of this exercise is to calculate a simple 'back of the envelope' approximation for the many power plants in the Eastern grid.

${ }^{34}$ The simulation of competitive imports results from actual prices $\left(p_{t}\right)$ exceeding the competitive price estimates $\left(p_{t}^{*}\right)$. For these hours, the competitive imports would be less than actual imports by the amount $\beta_{l} \cdot\left[\ln (p)-\ln \left(p^{*}\right)\right]$ where $\beta_{l}$ is estimated in Mansur (forthcoming) and differs by $l$ for peak and off-peak hours.
} 
Actual and simulated emissions may differ because of production complexities that the simulation does not take into account. ${ }^{35}$ I assume that these differences do not change over time.

In addition, strategic behavior increases imports relative to a competitive model. This results in more pollution in other areas. I use CEMS data on $r_{i j}$ and the $\widetilde{\delta}_{i}$ to calculate the increased emissions from imperfectly competitive behavior in PJM for the summer of 1999. I find that importing regions increased emissions only slightly (about 0.5 percent of PJM's actual emissions). ${ }^{36}$ As these emissions would not have occurred in a competitive market, I subtract them from the competitive estimates.

The changes in competitive estimates are between a half and two thirds of the changes in actual emissions. These estimates account for the emissions from imports. The competitive estimates predict a reduction of nine, 13 , and six percent for $\mathrm{SO}_{2}, \mathrm{NO}_{x}$, and $\mathrm{CO}_{2}$ emissions, respectively. I attribute the difference between these percentages (six, eight, and three percent, respectively) to market imperfections such as firms setting prices. ${ }^{37}$

Table 9 examines the changes in PJM emissions by month. For each month, I examine the difference between the actual emissions and simulated counterfactual emissions. Relative to the monthly differences in 1998, $\mathrm{SO}_{2}$ emissions were lower in all months of the summer of 1999 . This is also the case for all of the months for $\mathrm{NO}_{x}$ emissions and half of the months for $\mathrm{CO}_{2}$ emissions. In particular, April and July saw large reductions from the competitive model (relative to those months in 1998) for all pollutants.

The findings of Tables 8 and 9 suggest that, of the observed reduction in $\mathrm{SO}_{2}$ emissions from 1998 to 1999, 42 percent resulted from market imperfections. For $\mathrm{NO}_{x}$ emissions, I attribute 36 percent of the actual reduction to imperfections. Finally, for $\mathrm{CO}_{2}$ emissions, 33 percent of the actual reductions are attributed to strategic behavior and other market imperfections. These results are robust to alternative measures of emissions rates. ${ }^{38}$

\footnotetext{
${ }^{35}$ Cost non-convexities arise because of intertemporal constraints, or unit commitment problems, such as start up costs and ramp rates. When a firm starts a unit, it incurs large costs. This will alter how actual units are used relative to the competitive model in Mansur (forthcoming). Mansur (2005) discusses how these costs may impact welfare calculations.

${ }^{36} \mathrm{SO}_{2}$ emissions increased 1637 tons. $\mathrm{NO}_{x}$ emissions increased 722 tons. $\mathrm{CO}_{2}$ emissions increased 339,018 tons.

${ }^{37}$ In addition to market power, inefficiencies could also be caused by non-strategic firm behavior (e.g., misunderstanding marginal costs) or by the market maker, PJM (e.g., flaws in the pricing algorithm). Note that the environmental impacts of restructuring hold regardless of why the production efficiencies occurred. These environmental effects will be overstated if permits are endogenous (see Mansur, 2006).

${ }^{38}$ As mentioned in footnote 30, the identification of the units in CEMS and PROSYM did not match for many units. I test the robustness of this assumption using only the CEMS rates. In general, the CEMS rates are greater
} 


\section{Discussion of Environmental Implications}

This section discusses the environmental implications of restructuring. In particular, I determine the value of the pollution reductions that resulted from firms exercising market power in PJM. Under tradable permit systems, production distortions cannot affect aggregate emissions. These systems place system-wide caps on the total amount of pollution emitted. The firms can trade permits for the right to pollute so long as the total cap is not exceeded. Reducing demand for permits in one part of the system allows for increased pollution elsewhere. Although aggregate emissions will be unaffected, the distribution of pollution may change as a result of firms exercising market power. This emission distribution could be of potential importance if environmental and health damages depend on spatial and temporal factors. ${ }^{39}$

However, if the imports came from outside of the OTC region, such as from Ohio, then exercising market power would increase the overall $\mathrm{NO}_{x}$ emissions. Any emissions reduction in Delaware, New Jersey, or Pennsylvania will be offset by increases within the OTC region, either across space or time, due to the trading and banking nature of the pollution cap. Thus, importing electricity from Ohio will result in even more emissions. This may not be the case for $\mathrm{SO}_{2}$, as only some firms were regulated by Phase I, or for unregulated $\mathrm{CO}_{2}$.

Even if no health or environmental effects resulted from restructuring the PJM electricity market, the reduction in emissions by PJM firms has economic effects. Since less pollution occurred in PJM, there are temporarily more unused permits available. Firms elsewhere in the OTC tradable permit market, like in New York, can now purchase these permits. The total pollution level will be the same in equilibrium, but now the firm in New York no longer needs to install expensive abatement technology as it would have done without the excess permits from PJM. In other words, society forgoes expenditures on abatement technology, reducing the overall cost associated with complying with environmental regulation.

In order to measure the economic consequences of the pollution reductions, I make the following assumptions. I assume that the $\mathrm{SO}_{2}$ and $\mathrm{NO}_{x}$ permit markets are competitive, implying that the

than the PROSYM rates. When using only the units with PROSYM rates, the percentage share of the emissions reductions that I attribute to strategic behavior is greater for $\mathrm{SO}_{2}(53.8 \%)$, smaller for $\mathrm{NO}_{x}(10.4 \%)$, and similar for $\mathrm{CO}_{2}(36.8 \%)$. As using only the units with PROSYM rates places more weight on the matching of the units, these findings are not highlighted as the main results.

${ }^{39}$ However, the issue of distributional effects is one of the optimal size of a permit system's region. 
permit prices accurately reflect the marginal cost to society of abating pollution. Furthermore, I assume that permit prices are exogenous to firm behavior. I also assume that the permit price reflects the marginal damages to society. If a firm not under a cap and trade permit system changes its emissions, then society values changes at the permit price. Finally, this paper does not put a monetary value on the $\mathrm{CO}_{2}$ reductions. The value of $\mathrm{SO}_{2}$ and $\mathrm{NO}_{x}$ emission reductions equals the permit prices times the amount of pollution that is reduced.

These assumptions lead to the following welfare implications. In the summer of 1999, I estimate that actual $\mathrm{SO}_{2}$ emissions were 41,883 tons below my competitive estimates. This amount equals less than one percent of the total reductions mandated by the Clean Air Act Amendments. Multiplying daily $\mathrm{SO}_{2}$ permit prices and emission reductions and aggregating over days yields a value of $\$ 10.4$ million. That summer's $\mathrm{NO}_{x}$ emissions were 26,024 tons below my competitive estimates. This amount equals about a third of the system's mandated reductions and corresponds to $\$ 30.0$ million. Therefore, over a single summer, the total value of reduced pollution in PJM is $\$ 40.4$ million.

While market power may have resulted in welfare gains because of reduced pollution, it is important to keep in mind that the overall welfare effects of exercising market power are negative and much larger. Even accounting for these environmental gains, Mansur (2005) estimates that the deadweight loss from strategic behavior in PJM during the summer of 1999 was $\$ 137$ million.

Ignoring any responsiveness of permit prices to PJM firm behavior will lead to estimates that overstate welfare losses and understate compliance cost savings. To influence permit prices, firms need to be relatively large in comparison to the permit market. PJM firms have historically emitted a substantial 68 percent of the $\mathrm{NO}_{x}$ emissions in the OTC market. The two firms that likely exercised market power, PECO and PPL, account for 14 percent of the OTC region's emissions. These strategic firms may be capable of affecting the $\mathrm{NO}_{x}$ permit price, depending on the price elasticity of abatement. ${ }^{40}$ Mansur (2006) examines how $\mathrm{NO}_{x}$ permit prices respond to market power in the PJM electricity market and quantifies the welfare impacts of policy choices.

\footnotetext{
${ }^{40}$ Even if no single firm exercises market power in the permit market, a shift in the marginal abatement cost function caused by firms exercising market power in the electricity market may affect permit prices.
} 


\section{Conclusions}

In the summer of 1999, firms in the PJM wholesale electricity industry exercised market power and caused production inefficiencies. Using a difference-in-difference model, I compare the actual emissions of strategic firms in PJM with various control groups. The strategic firms reduced $\mathrm{NO}_{x}$ emissions substantially from 1998 to 1999. Given the new environmental regulation, I compare these firms' reductions with the decisions of other firms and find that PECO and PPL (the oligopolists) reduced emissions by approximately 20 percent relative to other firms. Similar reductions are seen for $\mathrm{SO}_{2}$ and $\mathrm{CO}_{2}$ emissions.

I then measure the overall impacts of market power on pollution emissions by comparing observed behavior with estimates of competitive production choices. Between the summers of 1998 and 1999, actual $\mathrm{SO}_{2}$ emissions in PJM fell 15 percent, $\mathrm{NO}_{x}$ emissions fell 21 percent, and $\mathrm{CO}_{2}$ fell nine percent. Using a model of competitive behavior, I account for approximately 58 percent of the $\mathrm{SO}_{2}$ emission reductions typically attributed to new environmental regulation. The remaining 42 percent may be ascribed to market imperfections. For the $\mathrm{NO}_{x}$ and $\mathrm{CO}_{2}$ emission reductions, I attribute 36 and 33 percent of the reductions, respectively, to strategic behavior.

From a policy perspective, these emission reductions have both environmental and cost implications. In the case of $\mathrm{CO}_{2}$, which does not have a cap limiting total emissions, these findings imply lower environmental damages. When pollution markets exist, these findings imply lower costs of abatement for firms overall. Since less $\mathrm{NO}_{x}$ pollution occurred in PJM, to clear the market the extra permits from PJM will be sold at a lower price to firms elsewhere in the OTC tradable permit market. The total pollution level will be the same in equilibrium, however, now firms in New England and New York no longer need to abate as much as they would have done without the excess permits from PJM. For example, these firms may forgo installing expensive abatement technology. For $\mathrm{SO}_{2}$, Phase I of the Acid Rain Program capped total pollution only for some power plants. Therefore, market power may reduce both $\mathrm{SO}_{2}$ pollution in PJM and permit prices. While greater emissions from imports could potentially reduce or even reverse these pollution effects, I find the additional pollution from imports to be quite small. I conclude that, holding prices fixed, the reduced demand for $\mathrm{NO}_{x}$ and $\mathrm{SO}_{2}$ permits resulted in compliance cost savings of $\$ 40$ million. These savings are small relative to the overall welfare losses that result from the exercise of market power (Mansur, 2005). 


\section{Appendix}

This appendix reports the robustness checks of the main model results shown in Table 5, Column (4). The input price and load variables are likely to have different impacts on different types of power plants. I interact each of the covariates in Table 5, Column (4), with indicators of oil and natural gas (relative to coal), as well as with plant average heat rates by fuel type. Many of these variables are significant, though the $\mathrm{R}^{2}$ is similar to the main model. The findings support those of the main model. ${ }^{41}$ Models linear in $\mathrm{NO}_{x}$ emissions, with either linear or log covariates, imply similar findings as the main specification. For example, with the linear-linear model, oligopolists reduce emissions at their average power plant by 382 pounds per hour more than the northern PJM fringe (relative to a base of 2011 pounds per hour in the summer of 1998).

Another robustness check addresses censoring. There are no $\mathrm{NO}_{x}$ emissions for about 25 percent of the sample because a plant is not operating in a given hour. The results of a Tobit model-with indicators of fuel type, heat rates by fuel type, and the covariates of Column (4)-are qualitatively similar to the main results. This is supported by the findings of a selection model of whether to operate. Namely, a linear probability model with the same specification as Table 5, Column (4), finds that the only groups with significant changes in emissions are the southern fringe-which operates more frequently, 0.050 (0.022)-and the oligopolists, relative to the northern fringe, after the start of the OTC regulation (which operate less frequently, -0.061 (0.030)).

Finally, I test the error structure assumptions. Clustering at the firm level, under the assumption that a firm chooses all of its plants' production jointly, results in similar standard errors as in Column (4) and all of the variables subject to the OTC regulation are significant at the five percent level. I also compute the Newey-West standard errors for Column (4), assuming a six hour lag structure, and reach similar conclusions. Finally, the main results are robust to a generalized least squares AR(1) model using the Prais-Winsten method.

\footnotetext{
${ }^{41}$ New York plants reduce emissions by 18.7 percent (with a standard error of 7.9 percent). The changes in emissions by southern and northern fringe firms are insignificant with coefficients of -0.206 (s.e. 0.131) and 0.070 (0.111). Relative to the northern fringe firms, the oligopolists do not behave differently before the OTC regulation: -0.159 (0.212). After the OTC regulation, the northern fringe firms reduce $\mathrm{NO}_{x}$ emissions by 36.8 percent (9.2 percent). Relative to this change, the oligopolists reduce emissions by 18.1 percent (10.9 percent) after the OTC regulation, which is significant at the 10 percent level. A Wald test finds that, after the OTC regulation, oligopolists behave differently than the New York firms $(F=10.69$, Prob $=0.001)$.
} 


\section{References}

[1] Asch, Peter and Joseph J. Seneca. 1976. "Monopoly and External Costs: An Application of Second-Best Theory to the Automobile Industry," Journal of Environmental Economics and Management, 3: 69-79.

[2] Bertrand, Marianne, Esther Duflo, and Sendhil Mullainathan. 2004. "How Much Should We Trust Differences-in-Differences Estimates?" Quarterly Journal of Economics, 119: 249-275.

[3] Borenstein, Severin. 2002. "The Trouble with Electricity Markets: Understanding California's Restructuring Disaster," Journal of Economic Perspectives, 16(1): 191-211.

[4] Borenstein, Severin, James B. Bushnell, and Frank A. Wolak. 2002. "Measuring Market Inefficiencies in California's Restructured Wholesale Electricity Market," American Economic Review, 92(5): 1376-1405.

[5] Buchanan, James. 1969. "External Diseconomies, Corrective Taxes, and Market Structure," American Economic Review, 59(1): 174-177.

[6] Burtraw, Dallas, Alan Krupnick, Karen Palmer, Anthony Paul, Mike Toman and Cary Bloyd. 2003. "Ancillary Benefits of Reduced Air Pollution in the United States from Moderate Greenhouse Gas Mitigation Policies in the Electricity Sector," Journal of Environmental Economics and Management, 45(3): 650-673.

[7] Bushnell, James B. and Erin T. Mansur. 2005. "Consumption under Noisy Price Signals: A Study of Electricity Retail Rate Deregulation in San Diego," Journal of Industrial Economics, 53(4): 493-513.

[8] Bushnell, James B. and Celeste Saravia. 2002. "An Empirical Assessment of the Competitiveness of the New England Electricity Market," University of California Energy Institute CSEM Working Paper-101.

[9] Dnes, Anthony W. 1981. "The Case of Monopoly and Pollution," Journal of Industrial Economics, 30(2): 213-216.

[10] Endres, Alfred. 1978. "Monopoly-Power as a Means for Pollution-Control?" Journal of Industrial Economics, 27(2): 185-187.

[11] Fowlie, Meredith. 2005. "Emissions Trading, Electricity Industry Restructuring, and Investment in Pollution Abatement," University of California Energy Institute CSEM Working Paper-149.

[12] Fullerton, Don and Gilbert E. Metcalf. 2002. "Cap and Trade Policies in the Presence of Monopoly and Distortionary Taxation," Resource and Energy Economics, 24(4): 327-347.

[13] Joskow, Paul L. and Edward Kahn. 2002. "A Quantitative Analysis of Pricing Behavior In California's Wholesale Electricity Market During Summer 2000," Energy Journal 23(4): 1-35.

[14] Kahn, Edward. 2000. Workpapers in Public Utilities Commission of Ohio, Case No. 99-ELETP. 
[15] Levin, Dan. 1985. "Taxation within Cournot Oligopoly," Journal of Public Economics, 27(3): 281-290.

[16] Mansur, Erin T. 2005. "Measuring Welfare in Restructured Electricity Markets," Yale Mimeo.

[17] — 2006. "Prices vs. Quantities: Environmental Regulation and Imperfect Competition," Yale Mimeo.

[18] —. Forthcoming. "Upstream Competition and Vertical Integration in Electricity Markets," Journal of Law and Economics.

[19] Market Monitoring Unit. 2001. PJM Interconnection State of the Market Report 2000. June.

[20] Palmer, Karen, Dallas Burtraw, and Jhih-Shyang Shih. Forthcoming. "The Benefits and Costs of Reducing Emissions from the Electricity Sector," Journal of Environmental Management.

[21] Puller, Steven L. Forthcoming. "Pricing and Firm Conduct in California's Deregulated Electricity Market," Review of Economics and Statistics.

[22] Simpson, David R. 1995. "Optimal Pollution Taxation in a Cournot Duopoly," Environmental and Resource Economics, 6(4): 359-69.

[23] Wolak, Frank A. and Robert H. Patrick. 1997. "The Impact of Market Rules and Market Structure on the Price Determination Process in the England and Wales Electricity Market," University of California Energy Institute POWER Working Paper-04\%.

[24] Wolfram, Catherine D. 1998. "Strategic Bidding in a MultiUnit Auction: An Empirical Analysis of Bids to Supply Electricity in England and Wales," RAND Journal of Economics, 29(4): 703-725.

[25] — 1999. "Measuring Duopoly Power in the British Electricity Spot Market," American Economic Review, 89(4): 805-826. 


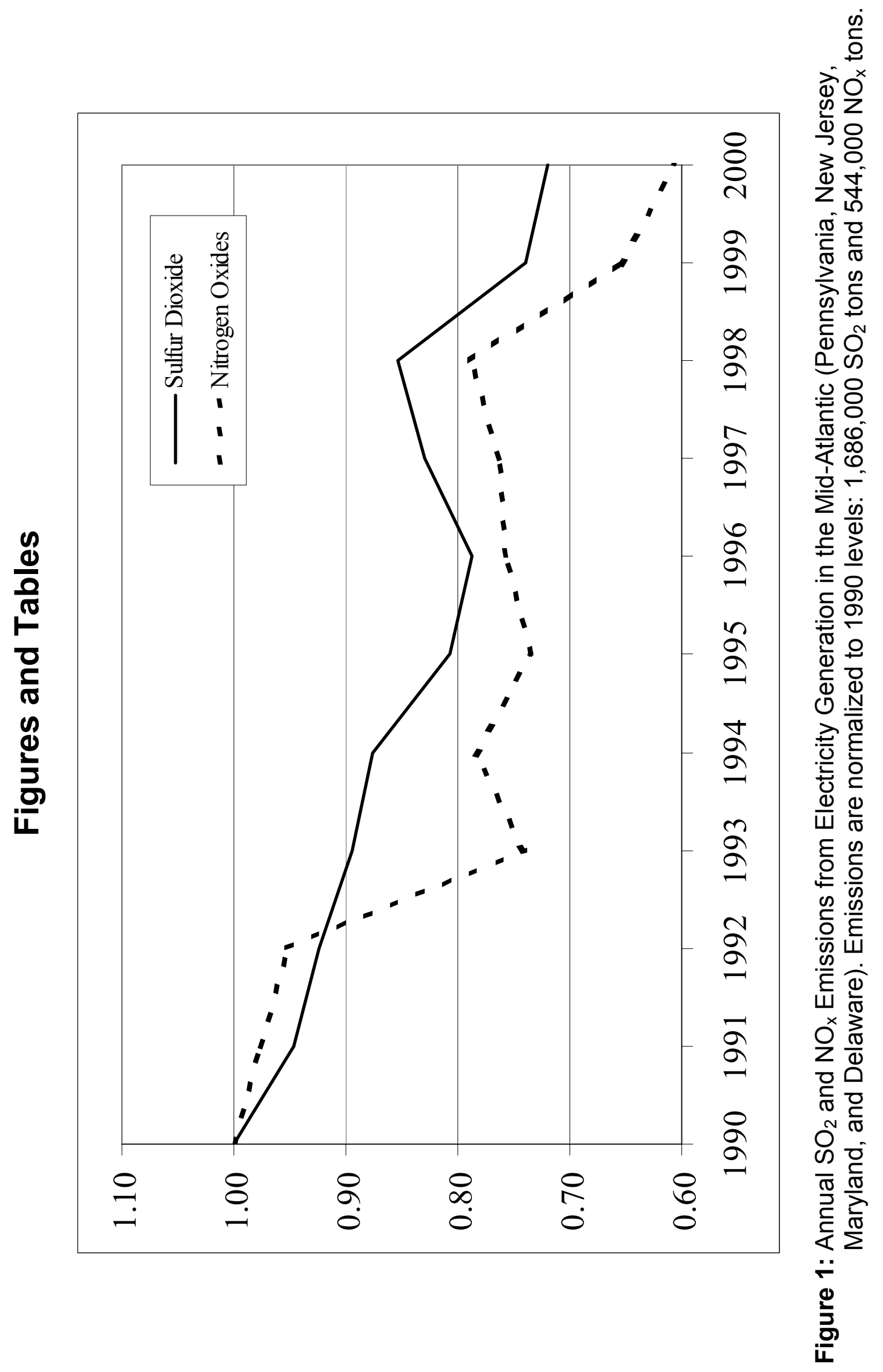




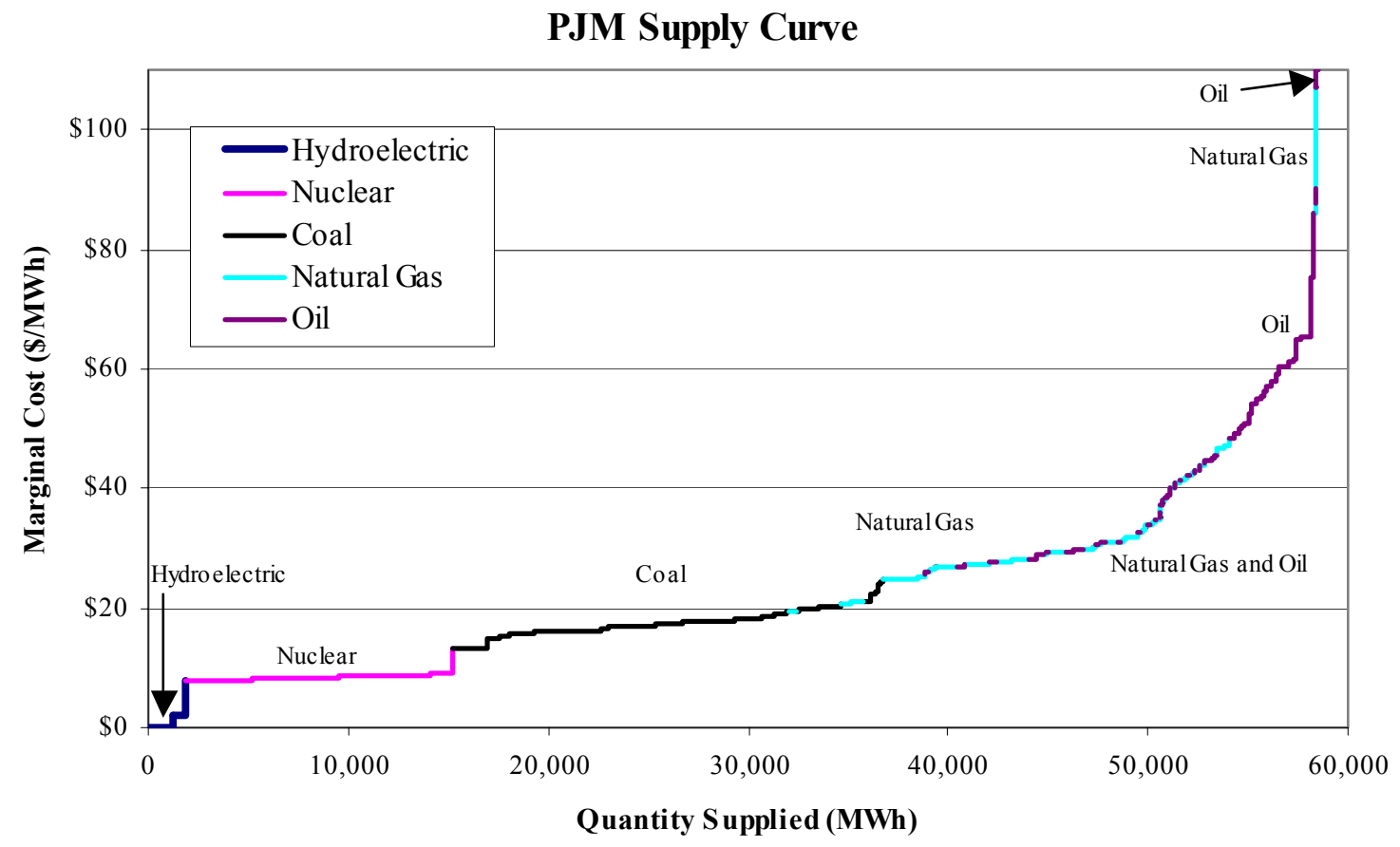

Figure 2: PJM Market-Wide Supply Curve on April 1, 1999 (source: Mansur, 2005c).

PJM Sulfur Dioxide Emis s ions Curve

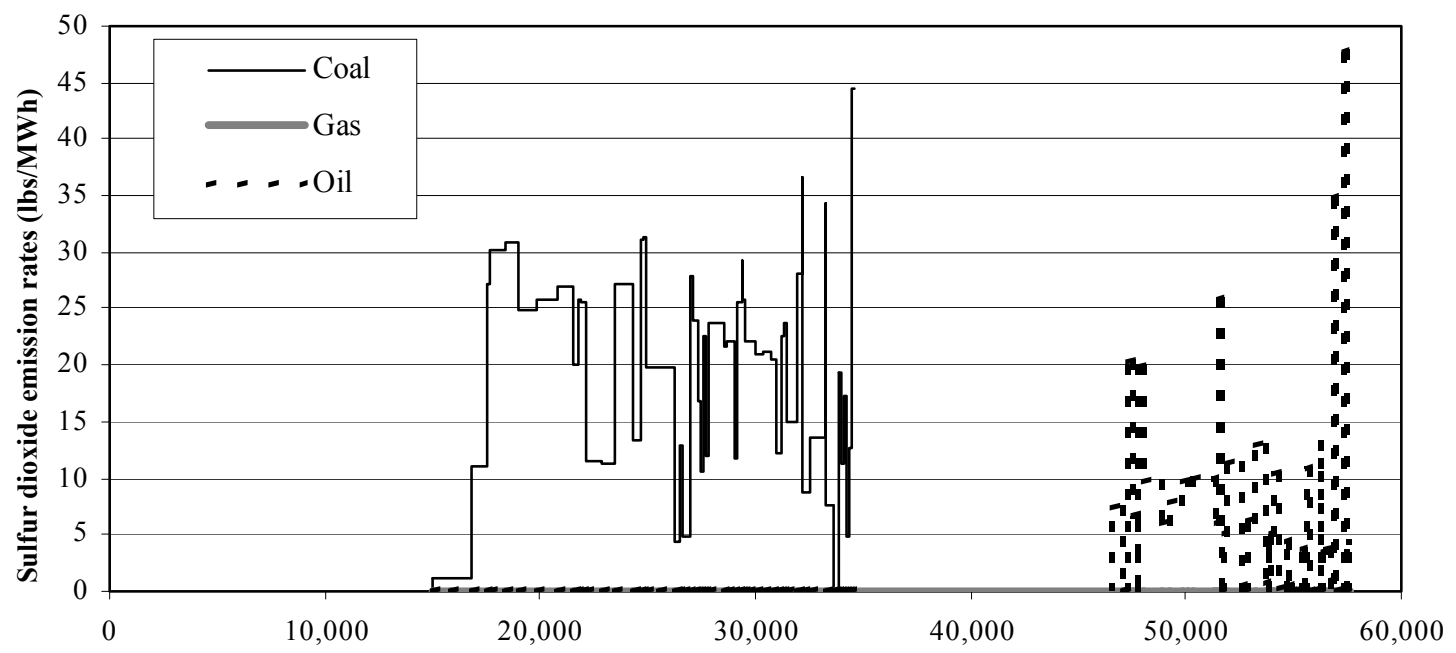

Figure 3: $\mathrm{SO}_{2}$ Emissions Rates Varying Along the Supply Curve. 
Table 1: PJM Firm Characteristics

Panel A: Generation Capacity by Firm and Fuel Type ${ }^{a}$

\begin{tabular}{lrrrrr}
\hline \hline Firm & Coal & Oil & Gas & Water & Nuclear \\
\hline Public Service Electric ${ }^{b}$ & 1,607 & 1,842 & 3,311 & - & 3,510 \\
PECO & 895 & 2,476 & 311 & 1,274 & 4,534 \\
GPU, Inc. & 5,459 & 1,816 & 203 & 454 & 1,513 \\
PPL Inc. & 3,923 & 478 & 1,701 & 148 & 2,304 \\
Potomac Electric Power & 3,082 & 2,549 & 876 & - & - \\
Baltimore Gas \& Electric & 2,265 & 925 & 755 & - & 1,829 \\
Delmarva Power \& Light & 1,259 & 888 & 311 & - & - \\
Atlantic City Electric & 391 & 436 & 482 & - & - \\
Other $^{c}$ & 2,087 & 353 & - & 439 & - \\
\hline Total $_{\text {Market Share }}$ & 20,967 & 11,762 & 7,949 & 2,316 & 13,690 \\
\hline \hline
\end{tabular}

Panel B: Market Shares of Capacity, Generation, and Demand

\begin{tabular}{|c|c|c|c|}
\hline \multirow[t]{2}{*}{ Firm } & & & Demand \\
\hline & Capacity & Generation $^{d}$ & Served $^{\mathrm{e}}$ \\
\hline Public Service Electric & $18.1 \%$ & $14.0 \%$ & $17.3 \%$ \\
\hline PECO & $16.7 \%$ & $17.8 \%$ & $8.8 \%$ \\
\hline GPU, Inc. & $16.7 \%$ & $19.8 \%$ & $14.7 \%$ \\
\hline PPL Inc. & $15.1 \%$ & $15.9 \%$ & $9.9 \%$ \\
\hline Potomac Electric Power & $11.5 \%$ & $10.1 \%$ & $10.4 \%$ \\
\hline Baltimore Gas \& Electric & $10.2 \%$ & $12.5 \%$ & $11.2 \%$ \\
\hline Delmarva Power \& Light & $4.3 \%$ & $3.2 \%$ & $6.0 \%$ \\
\hline Atlantic City Electric & $2.3 \%$ & $1.1 \%$ & $4.3 \%$ \\
\hline Other & $5.1 \%$ & $5.6 \%$ & $17.4 \%$ \\
\hline
\end{tabular}

Notes:

a) Data are from the Energy Information Administration (EIA) Form 860 for 1999. Capacity, in megawatts (MW), is listed by primary fuel type used in each generating unit at a power plant. Coal includes anthracite, bituminous coal, and petroleum coke. Oil includes No. 2, 4, and 6 fuel oil and kerosene. The other categories are natural gas, hydroelectric, and nuclear.

b) In 1999, the GPU parent company owned Jersey Central, GPU Nuclear, Metropolitan Edison and Pennsylvania Electric.

c) "Other" includes the following utilities: Safe Harbor Water Power, Easton Utilities, UGI Development, Allegheny Electric Coop, A\&N Electric Coop, and cities of Berlin, Dover, Lewes, Seaford, and Vineland.

d) Data are from EIA Form 759, over the period of April 1 to September 30, 1999.

e) Demand served is share summer peak demand less direct access customers. On July 6 , 1999, the system-wide demand reached a peak of 51,700 MW. Source: EIA Form 861, 1999. In 1999, many Pennsylvania customers switched to alternative providers, leaving GPU (3.4 percent of total market demand), PECO (5.6 percent), and PPL (2.5 percent). "Other" demand includes direct access customers. Source: www.oca.state.pa.us. 
Table 2: Summary Statistics on Emission Rates by Fuel Type for Fossil Units

\begin{tabular}{|c|c|c|c|c|c|}
\hline $\begin{array}{l}\text { Fuel Type of } \\
\text { Unit }\end{array}$ & $\begin{array}{c}\text { Emissions } \\
\text { Type }\end{array}$ & Mean & $\begin{array}{l}\text { Standard } \\
\text { Deviation }\end{array}$ & Minimum & Maximum \\
\hline Coal & $\begin{array}{l}\mathrm{SO}_{2} \\
\mathrm{NO}_{\mathrm{x}} \\
\mathrm{CO}_{2}\end{array}$ & $\begin{array}{r}20.3 \\
5.8 \\
2197.9\end{array}$ & $\begin{array}{r}9.2 \\
2.9 \\
307.7\end{array}$ & $\begin{array}{r}1.2 \\
2.6 \\
1797.9\end{array}$ & $\begin{array}{r}44.6 \\
18.9 \\
3382.6\end{array}$ \\
\hline Natural Gas & $\begin{array}{l}\mathrm{SO}_{2} \\
\mathrm{NO}_{x} \\
\mathrm{CO}_{2}\end{array}$ & $\begin{array}{r}0.0 \\
0.9 \\
1423.3\end{array}$ & $\begin{array}{r}0.0 \\
0.8 \\
216.1\end{array}$ & $\begin{array}{r}0.0 \\
0.2 \\
1137.0\end{array}$ & $\begin{array}{r}0.0 \\
3.1 \\
1902.7\end{array}$ \\
\hline Oil & $\begin{array}{l}\mathrm{SO}_{2} \\
\mathrm{NO}_{\mathrm{x}} \\
\mathrm{CO}_{2}\end{array}$ & $\begin{array}{r}7.0 \\
3.5 \\
1789.5\end{array}$ & $\begin{array}{r}9.5 \\
2.7 \\
468.2\end{array}$ & $\begin{array}{r}0.0 \\
0.2 \\
383.8\end{array}$ & $\begin{array}{r}47.8 \\
16.3 \\
2990.1\end{array}$ \\
\hline All & $\begin{array}{l}\mathrm{SO}_{2} \\
\mathrm{NO}_{\mathrm{x}} \\
\mathrm{CO}_{2}\end{array}$ & $\begin{array}{r}12.5 \\
4.3 \\
1939.9\end{array}$ & $\begin{array}{r}11.7 \\
3.1 \\
459.2\end{array}$ & $\begin{array}{r}0.0 \\
0.2 \\
383.8\end{array}$ & $\begin{array}{r}47.8 \\
18 . \\
3382 .\end{array}$ \\
\hline
\end{tabular}

Notes: All emissions rates are expressed in pounds of pollutant per MWh. Data are from the EPA's Continuous Emissions Monitoring System (CEMS) over April 1 to September 30, 1998. In the CEMS data, there are 60 coal-fired generating units, 16 natural gas-fired units, and 48 oilfired units. 
Table 3: PJM Market Summary Statistics During Summers of 1998 and 1999

Panel A: Summer of 1998

\begin{tabular}{|c|c|c|c|c|c|}
\hline Variable & Units & Mean & $\begin{array}{l}\text { Std. } \\
\text { Dev. }\end{array}$ & Min & Max \\
\hline Quantity demanded ${ }^{a}$ & $\mathrm{MWh} / \mathrm{hr}$ & 29,650 & 6,482 & 17,461 & 48,469 \\
\hline Electricity price $^{a}$ & $\$ / M W h$ & $\$ 26.04$ & $\$ 43.46$ & $\$ 0.00$ & $\$ 999.00$ \\
\hline Natural gas price ${ }^{b}$ & $\$ / \mathrm{mmbtu}$ & $\$ 2.33$ & $\$ 0.25$ & $\$ 1.80$ & $\$ 2.81$ \\
\hline Oil price ${ }^{c}$ & \$/Barrel & $\$ 16.30$ & $\$ 1.36$ & $\$ 13.99$ & $\$ 19.17$ \\
\hline $\mathrm{SO}_{2}$ permit price ${ }^{\mathrm{d}}$ & $\$ /$ Ton & $\$ 172.44$ & $\$ 24.40$ & $\$ 136.50$ & $\$ 198.50$ \\
\hline $\mathrm{NO}_{\mathrm{x}}$ permit price $\mathrm{e}^{\mathrm{s}}$ & \$/Ton & $N / A$ & $N / A$ & $\mathrm{~N} / \mathrm{A}$ & $\mathrm{N} / \mathrm{A}$ \\
\hline
\end{tabular}

Panel B: Summer of 1999

\begin{tabular}{|c|c|c|c|c|c|}
\hline Variable & Units & Mean & $\begin{array}{l}\text { Std. } \\
\text { Dev. }\end{array}$ & Min & $\operatorname{Max}$ \\
\hline Quantity demanded $^{a}$ & $\mathrm{MWh} / \mathrm{hr}$ & 30,459 & 7,156 & 17,700 & 51,714 \\
\hline Electricity price $^{\mathrm{a}}$ & $\$ / M W h$ & $\$ 37.97$ & $\$ 100.99$ & $\$ 0.00$ & $\$ 999.00$ \\
\hline Natural gas price & $\$ / m m b t u$ & $\$ 2.60$ & $\$ 0.27$ & $\$ 2.08$ & $\$ 3.28$ \\
\hline Oil price ${ }^{\mathrm{c}}$ & \$/Barrel & $\$ 20.56$ & $\$ 2.91$ & $\$ 16.55$ & $\$ 26.04$ \\
\hline $\mathrm{SO}_{2}$ permit price ${ }^{d}$ & \$/Ton & $\$ 202.71$ & $\$ 9.23$ & $\$ 188.00$ & $\$ 211.50$ \\
\hline $\mathrm{NO}_{x}$ permit price ${ }^{\mathrm{e}}$ & \$/Ton & $\$ 2,406$ & $\$ 1,756$ & $\$ 0$ & $\$ 5,244$ \\
\hline
\end{tabular}

Notes:

a) Electricity price and quantity data from PJM Interconnection: www.pjm.com

b) Natural gas prices at Transco Zone 6 non-New York from Natural Gas Intelligence.

c) No. 2 heating oil sold at New York Harbor from the U.S. Energy Information Agency.

d) EPA reports monthly average trades of $\mathrm{SO}_{2}$ permits at two brokerage firms (Cantor Fitzgerald and Fieldston).

e) $\mathrm{NO}_{x}$ costs are from Cantor Fitzgerald's monthly price index. 
Table 4: Summer Generation by Ownership and Fuel Type

Panel A: Fringe Producers

\begin{tabular}{lrrrr}
\hline \hline Fuel Type & $\begin{array}{r}\text { Summer } \\
\text { of } 1998\end{array}$ & $\begin{array}{r}\text { Summer } \\
\text { of } 1999\end{array}$ & $\begin{array}{r}\text { Change } \\
\text { Cercent }\end{array}$ \\
\hline Coal & 45.66 & 37.83 & -7.83 & $-17 \%$ \\
Oil & 3.89 & 4.07 & 0.18 & $5 \%$ \\
Gas & 4.38 & 5.32 & 0.94 & $21 \%$ \\
\hline Fossil & 53.93 & 47.22 & -6.71 & $-12 \%$ \\
Other & 24.92 & 23.88 & -1.05 & $-4 \%$ \\
\hline Total & 78.85 & 71.09 & -7.76 & $-10 \%$ \\
\hline \hline
\end{tabular}

Panel B: PECO

\begin{tabular}{lrrrr}
\hline Fuel Type & $\begin{array}{r}\text { Summer } \\
\text { of } 1998\end{array}$ & $\begin{array}{r}\text { Summer } \\
\text { of } 1999\end{array}$ & Change & $\begin{array}{r}\text { Percent } \\
\text { Change }\end{array}$ \\
\hline Coal & 1.62 & 1.47 & -0.15 & $-9 \%$ \\
Oil & 1.26 & 0.96 & -0.30 & $-24 \%$ \\
Gas & 0.07 & 0.14 & 0.07 & $99 \%$ \\
\hline Fossil & 2.95 & 2.57 & -0.38 & $-13 \%$ \\
Other & 17.13 & 18.08 & 0.95 & $6 \%$ \\
\hline Total & 20.08 & 20.65 & 0.57 & $3 \%$ \\
\hline \hline
\end{tabular}

Panel C: PPL

\begin{tabular}{lrrrr}
\hline \hline Fuel Type & $\begin{array}{r}\text { Summer } \\
\text { of } 1998\end{array}$ & $\begin{array}{r}\text { Summer } \\
\text { of } 1999\end{array}$ & Change & $\begin{array}{r}\text { Percent } \\
\text { Change }\end{array}$ \\
\hline Coal & 11.30 & 9.06 & -2.24 & $-20 \%$ \\
Oil & 1.44 & 0.80 & -0.64 & $-44 \%$ \\
Gas & 0.21 & 0.51 & 0.31 & $149 \%$ \\
\hline Fossil & 12.95 & 10.38 & -2.57 & $-20 \%$ \\
Other & 7.41 & 8.08 & 0.66 & $9 \%$ \\
\hline Total & 20.36 & 18.45 & -1.91 & $-9 \%$ \\
\hline
\end{tabular}

Notes: Data are from the EIA's Form 759 during April-September, 1998 and 1999. Net generation is measured in millions of MWh. (Net generation equals gross generation minus the use by power plants for their equipment.) Other includes nuclear, hydroelectric, and waste heat generation. 
Table 5: Difference-in-Differences Model of $\mathrm{NO}_{x}$ Emissions

Dependent variable: Log of $\mathrm{NO}_{x}$ emissions (lbs.) by plant and hour during AprilSeptember of 1998 and 1999

\begin{tabular}{|c|c|c|c|c|c|}
\hline Variable & $(1)$ & $(2)$ & (3) & $(4)$ & (5) \\
\hline New York * MaySept99 & $\begin{array}{l}-0.067 \\
(0.067)\end{array}$ & $\begin{array}{l}-0.154^{*} \\
(0.067)\end{array}$ & $\begin{array}{l}-0.210^{*} \\
(0.080)\end{array}$ & $\begin{array}{l}-0.192^{*} \\
(0.078)\end{array}$ & $\begin{array}{l}-0.161^{*} \\
(0.078)\end{array}$ \\
\hline SoPJM * AprSept99 & $\begin{array}{l}-0.146 \\
(0.119)\end{array}$ & $\begin{array}{l}-0.200^{\#} \\
(0.116)\end{array}$ & $\begin{array}{l}-0.262^{*} \\
(0.122)\end{array}$ & $\begin{array}{l}-0.266^{*} \\
(0.122)\end{array}$ & $\begin{array}{l}-0.231^{\#} \\
(0.123)\end{array}$ \\
\hline NoPJM * Apr99 & $\begin{array}{l}-0.188^{*} \\
(0.082)\end{array}$ & $\begin{array}{c}0.026 \\
(0.085)\end{array}$ & $\begin{array}{l}-0.015 \\
(0.102)\end{array}$ & $\begin{array}{c}0.024 \\
(0.106)\end{array}$ & \\
\hline NoPJM * MaySept99 & $\begin{array}{l}-0.255^{*} \\
(0.071)\end{array}$ & $\begin{array}{l}-0.340^{*} \\
(0.073)\end{array}$ & $\begin{array}{l}-0.406^{*} \\
(0.094)\end{array}$ & $\begin{array}{l}-0.413^{*} \\
(0.094)\end{array}$ & \\
\hline NoPJM * AprSept99 & & & & & $\begin{array}{l}-0.317^{*} \\
(0.085)\end{array}$ \\
\hline Olig * NoPJM * Apr99 & $\begin{array}{l}-0.202 \\
(0.182)\end{array}$ & $\begin{array}{l}-0.202 \\
(0.184)\end{array}$ & $\begin{array}{l}-0.202 \\
(0.184)\end{array}$ & $\begin{array}{l}-0.202 \\
(0.184)\end{array}$ & \\
\hline Olig * NoPJM * MaySept99 & $\begin{array}{l}-0.214^{*} \\
(0.097)\end{array}$ & $\begin{array}{l}-0.222^{*} \\
(0.102)\end{array}$ & $\begin{array}{l}-0.221^{*} \\
(0.102)\end{array}$ & $\begin{array}{l}-0.222^{*} \\
(0.103)\end{array}$ & \\
\hline Olig * NoPJM * AprSept99 & & & & & $\begin{array}{l}-0.201^{\#} \\
(0.103)\end{array}$ \\
\hline Log of Natural Gas Price & & & $\begin{array}{r}0.296^{*} \\
(0.087)\end{array}$ & $\begin{array}{r}0.286^{*} \\
(0.087)\end{array}$ & $\begin{array}{r}0.203^{*} \\
(0.083)\end{array}$ \\
\hline Log of Oil Price & & & $\begin{array}{l}-0.020 \\
(0.142)\end{array}$ & $\begin{array}{l}-0.022 \\
(0.142)\end{array}$ & $\begin{array}{l}-0.096 \\
(0.144)\end{array}$ \\
\hline Log of $\mathrm{SO}_{2}$ Permit Price & & & $\begin{array}{c}0.198 \\
(0.153)\end{array}$ & $\begin{array}{c}0.155 \\
(0.158)\end{array}$ & $\begin{array}{c}0.131 \\
(0.160)\end{array}$ \\
\hline Log of Load & & $\begin{array}{r}1.442^{*} \\
(0.111)\end{array}$ & $\begin{array}{r}1.422^{*} \\
(0.110)\end{array}$ & $\begin{array}{c}\text { Spline } \\
\text { function }\end{array}$ & $\begin{array}{c}\text { Spline } \\
\text { function }\end{array}$ \\
\hline $\begin{array}{l}\mathrm{R}^{2} \\
\text { Sample size }\end{array}$ & $\begin{array}{c}0.82 \\
646,963\end{array}$ & $\begin{array}{c}0.85 \\
646,963 \\
\end{array}$ & $\begin{array}{c}0.85 \\
646,963 \\
\end{array}$ & $\begin{array}{c}0.85 \\
646,963\end{array}$ & $\begin{array}{c}0.85 \\
646,963 \\
\end{array}$ \\
\hline
\end{tabular}

Notes: * indicates significance at 5\% (\# at 10\%). Plant fixed effects are not shown. Standard errors are clustered by plant. In columns (4) and (5), the log of load is a five-piece spline function. The variables are: - MaySept99 indicating that the OTC NO regulation was in effect (for NY, NJ, PA, and DE);

- AprSept99 indicating that the PJM market was restructured (starting April 1, 1999, in all states but NY); Apr99 indicating that the PJM market was restructured but the OTC regulation was not yet in effect; SoPJM includes plants in MD, VA, and DC where the OTC regulation did not apply in 1999; - NoPJM includes plants in NJ, DE, and PA; and Olig includes the oligopolists, PECO and PPL. Most variables are exclusive with the exception of the oligopoly variables. E.g., "Olig * NoPJM * MaySept99" indicates that a plant is owned by an oligopolist (all oligopolists' plants are in NoPJM), and that restructuring and OTC regulation are in effect. The coefficient is the percent change relative to both (1) those plants' 1998 emissions and (2) the percent change by other firms in NoPJM * MaySept99. 


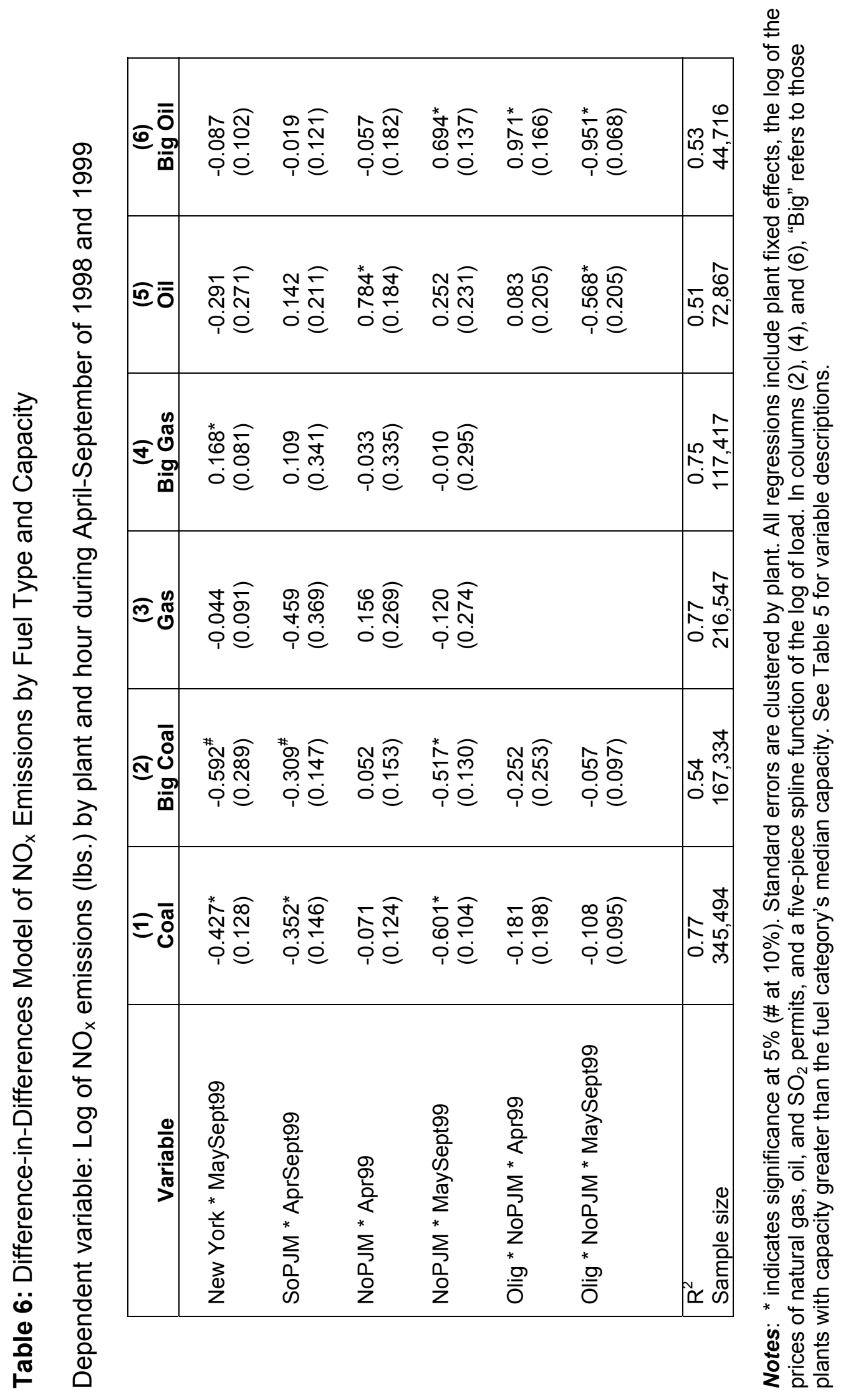


Table 7: Difference-in-Differences Model of All Emissions and Output

Dependent variables: $\mathrm{Log}$ of $\mathrm{NO}_{\mathrm{x}}$ emissions (lbs.), log of $\mathrm{SO}_{2}$ emissions (lbs.), log of $\mathrm{CO}_{2}$ emissions (tons), and log of electricity output (MWh) by plant and hour during April-September of 1998 and 1999

\begin{tabular}{|c|c|c|c|c|}
\hline Variable & $\begin{array}{c}\ln \left(\mathrm{NO}_{\mathrm{x}}\right) \\
(1)\end{array}$ & $\begin{array}{c}\ln \left(\mathrm{SO}_{2}\right) \\
(2)\end{array}$ & $\begin{array}{c}\ln \left(\mathrm{CO}_{2}\right) \\
(3)\end{array}$ & $\begin{array}{c}\operatorname{In} \text { (Output) } \\
(4)\end{array}$ \\
\hline New York * MaySept99 & $\begin{array}{l}-0.192^{*} \\
(0.078)\end{array}$ & $\begin{array}{l}-0.101 \\
(0.151)\end{array}$ & $\begin{array}{l}-0.029 \\
(0.067)\end{array}$ & $\begin{array}{l}-0.029 \\
(0.042)\end{array}$ \\
\hline SoPJM * AprSept99 & $\begin{array}{l}-0.266^{*} \\
(0.122)\end{array}$ & $\begin{array}{l}-0.083 \\
(0.108)\end{array}$ & $\begin{array}{l}-0.075 \\
(0.082)\end{array}$ & $\begin{array}{l}-0.009 \\
(0.051)\end{array}$ \\
\hline NoPJM * Apr99 & $\begin{array}{c}0.024 \\
(0.106)\end{array}$ & $\begin{array}{l}-0.052 \\
(0.209)\end{array}$ & $\begin{array}{c}0.094 \\
(0.085)\end{array}$ & $\begin{array}{r}0.198^{*} \\
(0.073)\end{array}$ \\
\hline NoPJM * MaySept99 & $\begin{array}{l}-0.413^{*} \\
(0.094)\end{array}$ & $\begin{array}{l}-0.164 \\
(0.133)\end{array}$ & $\begin{array}{l}-0.178^{*} \\
(0.083)\end{array}$ & $\begin{array}{l}-0.135^{*} \\
(0.067)\end{array}$ \\
\hline Olig * NoPJM * Apr99 & $\begin{array}{l}-0.202 \\
(0.184)\end{array}$ & $\begin{array}{l}-0.094 \\
(0.248)\end{array}$ & $\begin{array}{l}-0.285^{\#} \\
(0.155)\end{array}$ & $\begin{array}{l}-0.205^{\#} \\
(0.111)\end{array}$ \\
\hline Olig * NoPJM * MaySept99 & $\begin{array}{l}-0.222^{*} \\
(0.103)\end{array}$ & $\begin{array}{l}-0.219^{\#} \\
(0.121)\end{array}$ & $\begin{array}{l}-0.174^{\#} \\
(0.089)\end{array}$ & $\begin{array}{l}-0.135 \\
(0.096)\end{array}$ \\
\hline $\begin{array}{l}\mathrm{R}^{2} \\
\text { Sample size }\end{array}$ & $\begin{array}{l}0.85 \\
646,963 \\
\end{array}$ & $\begin{array}{l}0.87 \\
518,080 \\
\end{array}$ & $\begin{array}{l}0.80 \\
523,979 \\
\end{array}$ & $\begin{array}{l}0.82 \\
552,970\end{array}$ \\
\hline
\end{tabular}

Notes: * indicates significance at 5\% (\# at 10\%). Standard errors are clustered by plant. All regressions include plant fixed effects, the log of the prices of natural gas, oil, and $\mathrm{SO}_{2}$ permits, and a five-piece spline function of the log of load. See Table 5 for variable descriptions. 
Table 8: Simulation Results of PJM Summer Emissions

\begin{tabular}{|c|c|c|c|c|}
\hline & $\begin{array}{r}\text { Summer } \\
\text { of } 1998 \\
\end{array}$ & $\begin{array}{r}\text { Summer } \\
\text { of } 1999 \\
\end{array}$ & Change & $\begin{array}{l}\text { Percent } \\
\text { Change }\end{array}$ \\
\hline \multicolumn{5}{|l|}{$\mathrm{SO}_{2}$ Emissions (tons) } \\
\hline Actual & 631,898 & 539,602 & $-92,295$ & $-14.6 \%$ \\
\hline PJM competitive estimates & 513,780 & 471,897 & $-41,883$ & $-8.2 \%$ \\
\hline Change in import emissions & 0 & $-1,637$ & $-1,637$ & \\
\hline Total competitive estimates & 513,780 & 470,260 & $-43,520$ & $-8.5 \%$ \\
\hline Difference & $-118,118$ & $-69,343$ & $-48,775$ & $-6.1 \%$ \\
\hline Percent difference & & & & $42.0 \%$ \\
\hline \multicolumn{5}{|l|}{ NO ${ }_{x}$ Emissions (tons) } \\
\hline Actual & 174,063 & 138,014 & $-36,049$ & $-20.7 \%$ \\
\hline PJM competitive estimates & 202,919 & 176,895 & $-26,024$ & $-12.8 \%$ \\
\hline Change in import emissions & 0 & -722 & -722 & \\
\hline Total competitive estimates & 202,919 & 176,172 & $-26,746$ & $-13.2 \%$ \\
\hline Difference & 28,856 & 38,159 & $-9,303$ & $-7.5 \%$ \\
\hline Percent difference & & & & $36.4 \%$ \\
\hline \multicolumn{5}{|l|}{$\mathrm{CO}_{2}$ Emissions (1000s tons) } \\
\hline Actual & 74,704 & 67,728 & $-6,976$ & $-9.3 \%$ \\
\hline PJM competitive estimates & 87,981 & 82,848 & $-5,133$ & $-5.8 \%$ \\
\hline Change in import emissions & 0 & -339 & -339 & \\
\hline Total competitive estimates & 87,981 & 82,509 & $-5,472$ & $-6.2 \%$ \\
\hline Difference & 13,276 & 14,781 & $-1,505$ & $-3.1 \%$ \\
\hline Percent difference & & & & $33.4 \%$ \\
\hline
\end{tabular}

Notes: Had PJM been competitive, where competitive prices are below actual prices, firms would have imported less into PJM than they actually did. The corresponding changes in emissions are calculated for the summer of 1999. The summer of 1998 is assumed to be competitive. The total competitive estimates equal the sum of the competitive estimates in PJM and the change in the emissions from imports. The difference equals the total competitive estimates minus actual emissions. The percent difference is the ratio of this difference over actual emissions. 
Table 9: Monthly Comparison of Actual and Simulated Emissions

\begin{tabular}{|c|c|c|c|c|c|}
\hline & $\begin{array}{r}\text { Actual } \\
\text { Emissions }\end{array}$ & $\begin{array}{l}\text { Simulated } \\
\text { Emissions }\end{array}$ & Difference & $\begin{array}{l}\text { Monthly } \\
\text { Diff-in-Diff }\end{array}$ & $\begin{array}{l}\text { Percent } \\
\text { Change }\end{array}$ \\
\hline \multicolumn{6}{|c|}{$\mathrm{SO}_{2}$ Emissions (tons) } \\
\hline April, 1998 & 87,233 & 74,801 & 12,432 & & \\
\hline May & 92,514 & 83,976 & 8,538 & & \\
\hline June & 106,727 & 84,914 & 21,813 & & \\
\hline July & 126,015 & 93,284 & 32,731 & & \\
\hline August & 118,273 & 93,468 & 24,805 & & \\
\hline September & 101,136 & 83,337 & 17,799 & & \\
\hline April, 1999 & 78,813 & 78,580 & 233 & $-12,199$ & $-16 \%$ \\
\hline May & 66,139 & 62,761 & 3,377 & $-5,161$ & $-8 \%$ \\
\hline June & 87,557 & 75,278 & 12,280 & $-9,533$ & $-13 \%$ \\
\hline July & 112,980 & 89,974 & 23,006 & $-9,724$ & $-11 \%$ \\
\hline August & 103,673 & 86,888 & 16,785 & $-8,020$ & $-9 \%$ \\
\hline September & 90,440 & 78,417 & 12,023 & $-5,775$ & $-7 \%$ \\
\hline \multicolumn{6}{|c|}{ NO ${ }_{x}$ Emissions (tons) } \\
\hline April, 1998 & 25,771 & 27,304 & $-1,533$ & & \\
\hline May & 25,196 & 31,913 & $-6,718$ & & \\
\hline June & 28,882 & 34,034 & $-5,152$ & & \\
\hline July & 34,321 & 38,707 & $-4,386$ & & \\
\hline August & 33,488 & 38,390 & $-4,902$ & & \\
\hline September & 26,406 & 32,571 & $-6,165$ & & \\
\hline April, 1999 & 23,321 & 27,964 & $-4,643$ & $-3,110$ & $-11 \%$ \\
\hline May & 15,340 & 22,874 & $-7,534$ & -816 & $-4 \%$ \\
\hline June & 21,760 & 28,269 & $-6,509$ & $-1,357$ & $-5 \%$ \\
\hline July & 30,105 & 36,369 & $-6,264$ & $-1,878$ & $-5 \%$ \\
\hline August & 25,966 & 33,060 & $-7,094$ & $-2,191$ & $-7 \%$ \\
\hline September & 21,522 & 28,359 & $-6,837$ & -672 & $-2 \%$ \\
\hline \multicolumn{6}{|c|}{$\mathrm{CO}_{2}$ Emissions (1000s tons) } \\
\hline April, 1998 & 10,061 & 11,415 & $-1,354$ & & \\
\hline May & 10,823 & 13,647 & $-2,824$ & & \\
\hline June & 12,387 & 14,845 & $-2,458$ & & \\
\hline July & 15,714 & 17,083 & $-1,369$ & & \\
\hline August & 14,400 & 16,941 & $-2,542$ & & \\
\hline September & 11,320 & 14,049 & $-2,729$ & & \\
\hline April, 1999 & 9,645 & 12,600 & $-2,955$ & $-1,600$ & $-13 \%$ \\
\hline May & 8,464 & 10,732 & $-2,269$ & 555 & $5 \%$ \\
\hline June & 11,823 & 13,563 & $-1,739$ & 719 & $5 \%$ \\
\hline July & 14,684 & 17,714 & $-3,030$ & $-1,660$ & $-9 \%$ \\
\hline August & 12,781 & 15,408 & $-2,627$ & -85 & $-1 \%$ \\
\hline September & 10,331 & 12,832 & $-2,501$ & 228 & $2 \%$ \\
\hline
\end{tabular}

